\title{
Surface-to-mountaintop transport characterised by radon observations at the Jungfraujoch
}

\author{
A. D. Griffiths ${ }^{1}$, F. Conen ${ }^{2}$, E. Weingartner ${ }^{3, *}$, L. Zimmermann ${ }^{2}$, S. D. Chambers ${ }^{1}$, A. G. Williams ${ }^{1}$, and \\ M. Steinbacher ${ }^{4}$ \\ ${ }^{1}$ Australian Nuclear Science and Technology Organisation, New South Wales, Australia \\ ${ }^{2}$ Environmental Geosciences, Department of Geosciences, University of Basel, Basel, Switzerland \\ ${ }^{3}$ Laboratory of Atmospheric Chemistry, Paul Scherrer Institute, 5232 Villigen, Switzerland \\ ${ }^{4}$ Swiss Federal Laboratories for Materials Science and Technology (Empa), Dübendorf, Switzerland \\ *now at: Institute for Aerosol and Sensor Technology, University of Applied Sciences, 5210 Windisch, Switzerland
}

Correspondence to: A. D. Griffiths (alan.griffiths@ansto.gov.au)

Received: 5 May 2014 - Published in Atmos. Chem. Phys. Discuss.: 4 July 2014

Revised: 30 September 2014 - Accepted: 17 October 2014 - Published: 5 December 2014

\begin{abstract}
Atmospheric composition measurements at Jungfraujoch are affected intermittently by boundary-layer air which is brought to the station by processes including thermally driven (anabatic) mountain winds. Using observations of radon-222, and a new objective analysis method, we quantify the land-surface influence at Jungfraujoch hour by hour and detect the presence of anabatic winds on a daily basis. During 2010-2011, anabatic winds occurred on $40 \%$ of days, but only from April to September. Anabatic wind days were associated with warmer air temperatures over a large fraction of Europe and with a shift in air-mass properties, even when comparing days with a similar mean radon concentration. Excluding days with anabatic winds, however, did not lead to a better definition of the unperturbed aerosol background than a definition based on radon alone. This implies that a radon threshold reliably excludes local influences from both anabatic and non-anabatic vertical-transport processes.
\end{abstract}

\section{Introduction}

High-altitude mountain sites have long been recognised as suitable places for characterising the chemical composition of the lower troposphere. These sites can be used to make measurements that are representative of continental to hemispheric scales (Keeling et al., 1976), also known as the baseline (Calvert, 1990; Parrish et al., 2014), by focusing on air masses which have travelled far from emission sources and had time to mix. But local sources can still have an influence, depending largely on the recent history of vertical transport and associated mixing. This necessitates the development of carefully considered data selection techniques.

The task of understanding vertical transport becomes particularly complicated in mountainous terrain (Rotach and Zardi, 2007; Weissmann et al., 2005), which affects vertical exchange processes in site-specific ways that are not as well understood as processes occurring over flat terrain (Zardi and Whiteman, 2013). Because of this complexity, Stohl et al. (2009) found that Alpine sites were less useful than flat sites for constraining regional estimates of greenhouse gas emissions.

The High Altitude Research Station Jungfraujoch is a key European and Global Atmospheric Watch monitoring site with a long-term history in atmospheric research (Leuenberger and Flückiger, 2008). Local influences are felt during periods of enhanced vertical transport and need to be reliably accounted for during data interpretation. The site is located in a saddle, $3454 \mathrm{~m}$ a.s.l., on the north-west flank of the Swiss Alps (Fig. 1). Below station elevation, winds over the Swiss Plateau are channelled parallel to the mountain range, whereas above mountaintops winds are most frequently from the north-west with a broad unimodal maximum (Furger, 1992; Ketterer et al., 2014). At Jungfraujoch itself, however, terrain channels the wind into a bimodal distribution with maxima towards the north-west and south-east. 


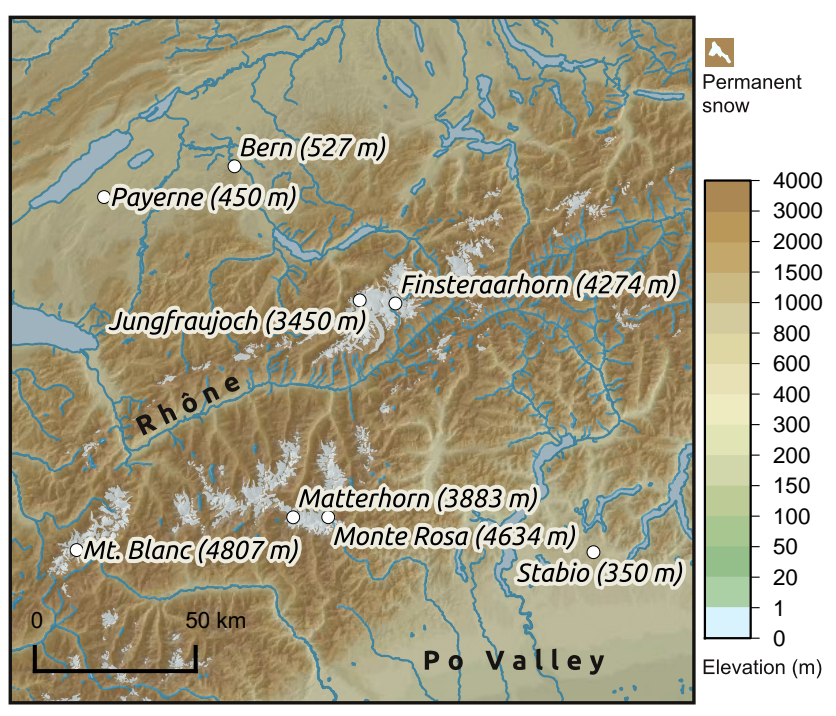

Figure 1. Jungfraujoch region. Radon detectors are installed at Jungfraujoch and Bern, separated horizontally by $61 \mathrm{~km}$.

Distinct pollution sources that have been identified at Jungfraujoch include: aerosols from the Swiss Plateau and Rhône Valley (De Wekker et al., 2004), a range of species from the industrialised Po Valley (Reimann et al., 2008, 2004; Seibert et al., 1998) and regional-scale European pollution, mainly from Switzerland, France and Germany (Uglietti et al., 2011). In addition to these surface sources, stratospheric incursions can affect air composition, especially ozone concentration (Stohl et al., 2000; Trickl et al., 2010).

Surface emissions can reach Jungfraujoch via several processes (Forrer et al., 2000). The most relevant ones (Zellweger et al., 2003) are as follows.

1. Thermally driven boundary-layer growth and anabatic mountain winds (Henne et al., 2004, 2005; Collaud Coen et al., 2011; De Wekker et al., 2004; Weigel et al., 2006; Kossmann et al., 1999; Zellweger et al., 2000).

2. Dynamically driven winds, including Föhn winds, in which the synoptic flow interacts with terrain (Drobinski et al., 2007; Campana et al., 2005; Lothon et al., 2003).

3. Deep vertical mixing over flat terrain followed by advection to the Alps. This can be associated with convection (active cumulus, or cumulonimbus formation) or frontal systems (Purvis et al., 2003). The Iberian Peninsula is a major source region (Cui et al., 2011).

Thermally driven or anabatic flows, the focus of this study, are most common under clear-sky, low-wind conditions in summer, when incoming solar radiation is strong (Henne et al., 2005). As well as the development of a deep convective boundary layer over the surrounding flat terrain, heating of the mountain slopes leads to a net buoyancy force, driving socalled anabatic upslope winds (Haiden, 2003; Mahrt, 1982). Weigel et al. (2006) documented a case where vertical exchange was enhanced by a factor of three compared with flat terrain. Convergence near mountain peaks further enhances the export of boundary-layer air to the free troposphere.

In aggregate, mountain ranges create an injection layer above and within their lee (Henne et al., 2005; Nyeki et al., 2000) which is dynamically decoupled from the convective boundary layer but has similar tracer concentrations. In order to feed the vertical transport, boundary-layer air is drawn towards the base of the mountains from up to $80 \mathrm{~km}$ away over the course of a day (Weissmann et al., 2005). The export of mass to the troposphere is significant at a regional scale and boundary-layer air is exported beyond the peak height even when the top of the boundary layer is lower over the Plateau (Ketterer et al., 2014). Henne et al. (2004) show a schematic in their Fig. 13 which summarises this conceptual model of flow processes on a fair-weather day.

Anabatic winds cause tracer measurements near mountain peaks to exhibit a diurnal cycle that is approximately sinusoidal in shape (Forrer et al., 2000; Whiteman, 2000). Unlike measurements in the boundary layer over flat terrain, which are typically characterised by peak values around dawn, the maximum occurs in the late afternoon as a result of boundary-layer air being brought to the mountain peak by anabatic winds. Tracer concentrations usually drop after the cessation of anabatic flow as the tracer injected during the day is carried away by free-troposphere winds. For sites near mountain summits, the onset of katabatic drainage flows in the evening can draw down tropospheric air from 500 to $1000 \mathrm{~m}$ above the site (Chambers et al., 2013; Perry et al., 1999; Ryan, 1997). Under calm tropospheric conditions, however, the influence of boundary-layer air injected into the troposphere by anabatic winds can persist well into the next day (Whiteman, 2000).

There has been an ongoing effort to characterise these local influences on Jungfraujoch observations. Previous studies made use of in situ measurements of surface-emitted tracers with a strong concentration contrast between the boundary layer and the free troposphere, such as aerosols (Collaud Coen et al., 2011), volatile organic compounds (VOCs) (Prévôt et al., 2000), CO (Forrer et al., 2000) and moisture (Henne et al., 2004, 2005), while others have incorporated back-trajectories (Balzani Lööv et al., 2008; Kossmann et al., 1999; Cui et al., 2011). While back-trajectories have proven to be effective during the winter months, they are less able to resolve anabatic mountain winds due to the small-scale nature of these processes. Consequently, meteorological, statistical or time-of-day filters (Andrews et al., 2011; Brooks et al., 2012; Zellweger et al., 2003) have been used to avoid periods influenced by anabatic winds. Yet another approach is to relate synoptic weather classifications to the occurrence of vertical transport (Collaud Coen et al., 2011). Data augmenting in situ measurements has included lidar, used to de- 
tect the top of aerosol layers (Nyeki et al., 2000; Gallagher et al., 2012; Ketterer et al., 2014), and radiosondes, which are launched from near the mountain and used to define the unperturbed free troposphere (Weiss-Penzias et al., 2006).

In this study we employ radon-222 (radon hereafter), an inert radioactive gas emitted from the ice-free land surface, and examine how useful it is for detecting anabatic winds at Jungfraujoch. Lugauer et al. (2000) demonstrated the feasibility of this approach at Jungfraujoch by measuring radon decay products attached to aerosol particles; with our method we are able to determine the concentration of radon itself, removing uncertainties due to the fraction of decay products which attach to aerosols, deposit on the ground or remain airborne.

Although other tracers, whether aerosols or surfaceemitted chemical species, have been used in a similar way, we argue that radon is a more reliable tracer of surface influence. It is emitted by all soils at a relatively constant rate (Szegvary et al., 2007; Zhang et al., 2011). Its only significant sink is radioactive decay. With a half-life of $3.8 \mathrm{~d}$, its tropospheric background concentration is low and temporal variations caused by changes in atmospheric transport are more clearly detectable than for other tracers with longer atmospheric lifetimes. Furthermore, seasonal snow cover attenuates emissions (Yamazawa et al., 2005) and we assume that emissions are negligible in the area with permanent snow cover surrounding Jungfraujoch, even though there are reports of sites above the snow line where the snow cover does allow radon to escape from the bedrock below (Pourchet et al., 2000).

Radon has previously been used to study vertical mixing based on temporal variations (Griffiths et al., 2013, and references therein) or on vertical profiles from aircraft (Guedalia et al., 1972; Lee and Cicerone, 1997; Williams et al., 2011), towers (Chambers et al., 2011; Grossi et al., 2012; Williams et al., 2013) or sites at different altitudes (Chevillard et al., 2002). Radon has been used for the estimation of local to regional surface emissions of trace gases (van der Laan et al., 2014), and has been incorporated into transport models as an auxiliary diagnostic of mixing (Vogel et al., 2013) or for testing transport or parameterisations (Feichter and Crutzen, 1990; Zhang et al., 2008). Other applications of groundbased detectors are reviewed by Zahorowski et al. (2004).

In a refinement of earlier studies (Gäggeler et al., 1995; Lugauer et al., 2000), we first use the Jungfraujoch radon measurements to rank days according to the strength of anabatic winds. Then - on the days of significant anabatic influence - we use radon measurements from a second detector, at Bern on the Swiss Plateau $(60 \mathrm{~km}$ north-west of and $3 \mathrm{~km}$ below Jungfraujoch), to assess the strength of vertical mixing between the Swiss Plateau and Jungfraujoch. We then examine the implications of anabatic winds, showing that their detection can be linked to meteorological observations (Sect. 3.2), and that anabatic winds influence air-mass properties (Sect. 3.3). Despite their successful identification and characterisation, we show that taking the presence of anabatic winds into account does not improve upon the identification of baseline air masses at Jungfraujoch. Instead, a simpler method based purely on a radon threshold is just as effective (Sect. 3.4) and retains a larger volume of data.

\section{Data and methods}

\subsection{Radon observations at Jungfraujoch and Bern}

Radon detectors have been operated continuously at Bern and Jungfraujoch since 2009. Here we use two full years of data from 2011 and 2012. The instruments are of the twofilter dual flow loop design, with a delay chamber of $400 \mathrm{~L}$ to remove thoron and a radon detection chamber of $750 \mathrm{~L}$ (Whittlestone and Zahorowski, 1998). This design eliminates an uncertainty inherent to progeny detectors (Xia et al., 2010) but means that the detectors are large and have a relatively slow response time.

The detectors respond to a step change in ambient concentration with a one-half rise time of $45 \mathrm{~min}$. Radon concentration, as a result, lags measurements made using faster sensors. We corrected for this by adjusting the calibrated radon concentrations using a lag of $1 \mathrm{~h}$, which maximised the correlation between radon and other tracers.

Operation of the detectors followed the protocol described by Chambers et al. (2011). Calibration was performed automatically every month by injecting a known amount of radon from a calibration source with an absolute uncertainty of $4 \%$ (Pylon Electronics). Instrument background was measured every three months. As well as being necessary for converting counts into radon concentration, the instrument background determines the lower limit of detection, defined as the concentration with a counting error of $30 \%$. For these instruments, the lower limit of detection was about $40 \mathrm{mBq} \mathrm{m}^{-3}$. At Jungfraujoch, where observed radon concentrations are $\gtrsim 100 \mathrm{mBq} \mathrm{m}^{-3}$ for $99 \%$ of the time, the counting error is small enough to be ignored.

Calibrated radon concentrations were converted from activity concentration at ambient conditions $\left(\mathrm{Bq} \mathrm{m}^{-3}\right)$ to a quantity which is conserved during an air parcel's ascent: activity concentration at standard temperature and pressure $\left(0^{\circ} \mathrm{C}, 1013 \mathrm{hPa}\right)$, written $\mathrm{Bq} \mathrm{m}^{-3} \mathrm{STP}$.

\subsection{Other parameters}

A wide range of meteorological and other parameters characterising the physical properties and chemical composition at Jungfraujoch are also routinely monitored. Trace gases are measured by Empa as part of Empa's operation of the Swiss National Air Pollution Monitoring Network. Aerosol properties are measured by the Paul Scherrer Institute in support of the Global Atmosphere Watch aerosol programme. MeteoSwiss operates one of their SwissMetNet stations at Jungfraujoch and continuously records an extended set of 
meteorological parameters. Some of these data are archived in the EBAS database (NILU, 2012) and by the World Data Centre for Greenhouse Gases (WDCGG; WMO, 2012). The measurements employed in this study were hourly averages of $\mathrm{CO}$ (measured by nondispersive infrared absorption) and total reactive nitrogen $\left(\mathrm{NO}_{\mathrm{y}}\right.$, measured by chemiluminescence), standard meteorological observations, and nephelometer measurements of the aerosol light scattering coefficient at $450 \mathrm{~nm}$. The nephelometer measurements were obtained from EBAS, the other parameters from WDCGG. See for example Zellweger et al. (2009), Pandey Deolal et al. (2012), Cozic et al. (2008) and Appenzeller et al. (2008) for more details on $\mathrm{CO}, \mathrm{NO}_{\mathrm{y}}$, aerosol properties and meteorological observations at Jungfraujoch, respectively.

\subsection{Transport simulations (back-trajectories)}

Backwards-trajectory simulations were performed using the Hybrid Single Particle Lagrangian Integrated Trajectory (HYSPLIT) model, version 4 (Draxler and Hess, 1998) forced with meteorological data at one-degree resolution from the National Centers for Environmental Prediction Global Data Assimilation System (NCEP GDAS) model. The forcing data are three-hourly on 23 pressure levels (the first 10 from the surface are 1000, 975, 950, 925, 900, 850, $800,750,700$ and $650 \mathrm{hPa}$ ) and were accessed via the HYSPLIT website (ARL, 2013). The trajectories are primarily used as an indicator of synoptic-scale flow direction, characterised by the back-bearing to Jungfraujoch after reaching a distance of $61 \mathrm{~km}$ from the receptor (the distance between Bern and Jungfraujoch). The particle release height matches the station elevation, $3.5 \mathrm{~km}$ a.s.l. $(\sim 650 \mathrm{hPa})$, but is $2.2 \mathrm{~km}$ above the GDAS topography. Folini et al. (2008) discuss the impact of the chosen receptor height, observing that a choice close to the station elevation, rather than near the model ground level, is more likely to reproduce the observed pattern of horizontal winds.

\subsection{Anabatic wind detection}

\subsubsection{Method description}

In common with previous investigators (Prévôt et al., 2000; Gallagher et al., 2011), the central feature of our method is the recognition that anabatic mountain winds are associated with a diurnal cycle in tracer concentrations near mountaintops, peaking in the afternoon. However, while previous investigators, such as Gallagher et al. (2011), fitted a sinusoid to daily measurements, our approach avoids imposing a constraint on the shape of the diurnal cycle. Furthermore, unlike Prévôt et al. (2000), who used VOCs as a surface tracer, we do not normalise by the near-surface value because of the relative homogeneity of radon emissions compared with many other species, including VOCs.
In overview, the procedure involves computing the diurnal composite of the set of all observed days and then removing days from the set in the order which most quickly reduces the mean square amplitude of the set's composite diurnal cycle.

In detail, the steps are as follows.

1. Fill gaps in the tracer time series by linear interpolation, provided they are at most $3 \mathrm{~h}$ long.

2. Split the time series into $24 \mathrm{~h}$ segments beginning at 07:00 UTC, the time of minimum radon concentration in the annual average diurnal composite (the seasonal variation in the time of the radon minimum is small).

3. Discard days with missing data (23\% of days in our data).

4. From each $24 \mathrm{~h}$ segment, subtract the mean of the segment's radon concentration values. The resultant unordered set of $24 \mathrm{~h}$ segments is called the input set.

5. Compute the diurnal composite of all segments in the input set and calculate its mean square value.

6. For each segment in the input set:

a. compute a diurnal composite from all segments in the input set except for the current one; then

b. calculate the mean square value of the new diurnal composite, and compare it to the value obtained from the original composite in step 5.

7. The segment whose exclusion reduces the composite's mean square value the most, has its original mean value (the value subtracted in step 4) added back in, and is then transferred from the input set to an ordered output list; the first segment (or day) is given an anabatic rank of 1 and so on.

8. Steps 5-7 are repeated until the input set is empty.

Once the set of $24 \mathrm{~h}$ segments, or days, is ordered by degree of anabatic influence, each day's radon load is partitioned into three components as a secondary diagnostic. This is illustrated in Fig. 2. A running diurnal composite is computed for each day, $i$, in the output list using the days ranked $i-5$ to $i+5$. The derived components are

1. background radon, the minimum of the running diurnal composite;

2. anabatic radon, the mean of the running diurnal composite minus background; and

3. non-anabatic radon, the daily mean minus the composite mean. 


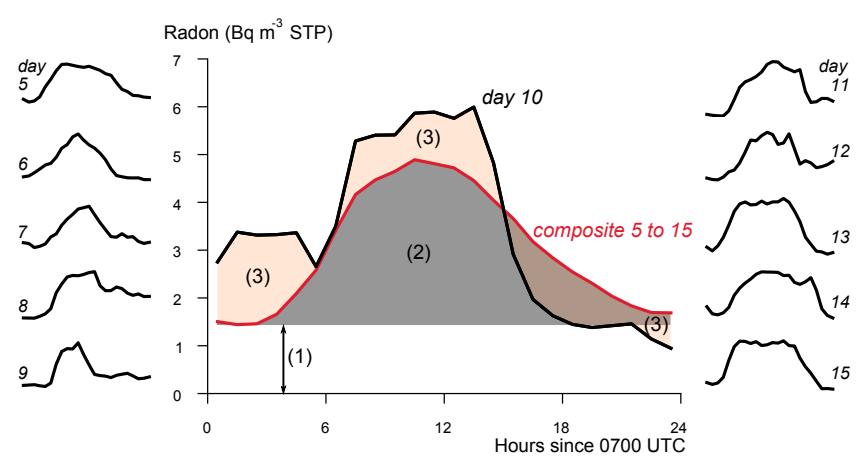

Figure 2. The definition of diagnostic quantities computed after ranking days by their contribution to the radon diurnal composite, termed the anabatic rank. Diagnostics for the $i$ th day, day 10 in this example, are computed from the $i$ th day radon concentration and the composite of days ranked from $i-5$ to $i+5$. These are: (1) baseline, the minimum of the composite; (2) anabatic, the mean of the composite; and (3) non-anabatic, the mean of the $i$ th day minus the mean of the composite.

The main reason for diagnosing anabatic radon is to identify a threshold rank, below which anabatic winds are absent. By inspecting a plot of anabatic rank vs. anabatic radon, Fig. 3, the threshold can be identified from when the anabatic radon concentration first reaches a minimum; day 220 in this case. Days with a rank below this threshold are defined as anabatic; all remaining days are classified as non-anabatic.

Irrespective of classification, periods of low radon concentration mean that the air being sampled is most likely representative of unperturbed free-tropospheric background values, whereas high radon concentrations on non-anabatic days likely correspond to periods of strong non-anabatic vertical transport. The classification differentiates between transport mechanisms.

Radon concentration variability leads to scatter in the anabatic radon concentration, making it prudent to select the threshold by inspection. If the method were perfect, the anabatic radon concentration would be zero for days above the threshold. For certain analyses, it could even be appropriate to set the anabatic radon to zero above the identified threshold. Without applying such a correction, the diagnosed anabatic radon concentration increases with rank for days above 220. This is a result of increasing intra-day variability, leading to a $10 \mathrm{~d}$ running composite that is both small in amplitude and noisy. This results in an increasing chance that random fluctuations are both in phase with the running composite and of comparable magnitude.

\subsubsection{Misclassification error}

As a further diagnostic we make an estimate of the falsepositive error rate, expressed in terms of the average radon concentration which is mistakenly classified as being due to anabatic flows. We expect that false positives will be present

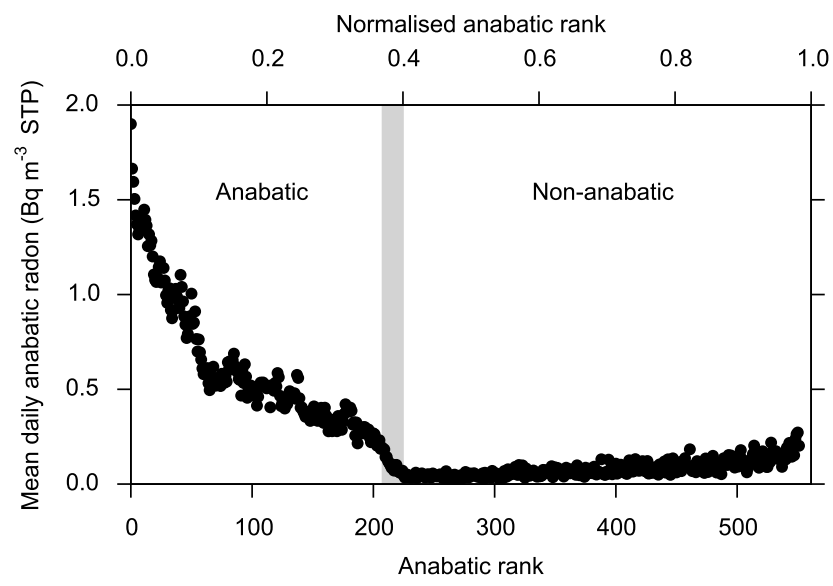

Figure 3. The daily mean anabatic radon concentration as a function of anabatic rank. Days with a rank above 220 (when the anabatic radon concentration first reaches its minimum) have a diurnal radon variation which is uncharacteristic of anabatic flows and are classified as non-anabatic. The increase in anabatic contribution after the minima is an artefact of the method.

because the detection of anabatic influence relies on finding days with a diurnal radon variation which is in phase with the running composite mean. Because of random fluctuations in the timing of nonthermal mixing, some days may have an inphase radon cycle in the absence of thermally forced flows.

To compute the error we selectively sub-sample the observed radon time series, obtaining a collection of days with a diurnal cycle (both individually and in composite) which is clearly due to processes other than anabatic flows. Then we apply the ranking procedure to this sub-sample of days knowing that all of the days classified as anabatic by this process are false positives. The results from the ranking procedure, including diagnostics, are used to make an estimate of the false-positive rate for the full time series.

The sub-sample is generated by selecting all days whose radon concentration signal, lagged by $12 \mathrm{~h}$, is positively correlated with the composite mean of the full data set; in other words we select days which appear to have anabatic mountain winds during the night. Then, the mean daily anabatic radon concentration in the full data set due to misclassified non-anabatic processes is given by

$a_{\mathrm{m}}=\frac{1}{N} \sum_{i=1}^{N_{\mathrm{s}}} a_{\mathrm{s}}^{(i)}$,

where $a_{\mathrm{m}}$ is the anabatic radon concentration due to misclassification, $a_{\mathrm{s}}^{(i)}$ is the anabatic radon concentration on the $i$ th day in the subset described above, $N$ is the number of days in the full data set and $N_{\mathrm{S}}$ is the number of days in the subset. 

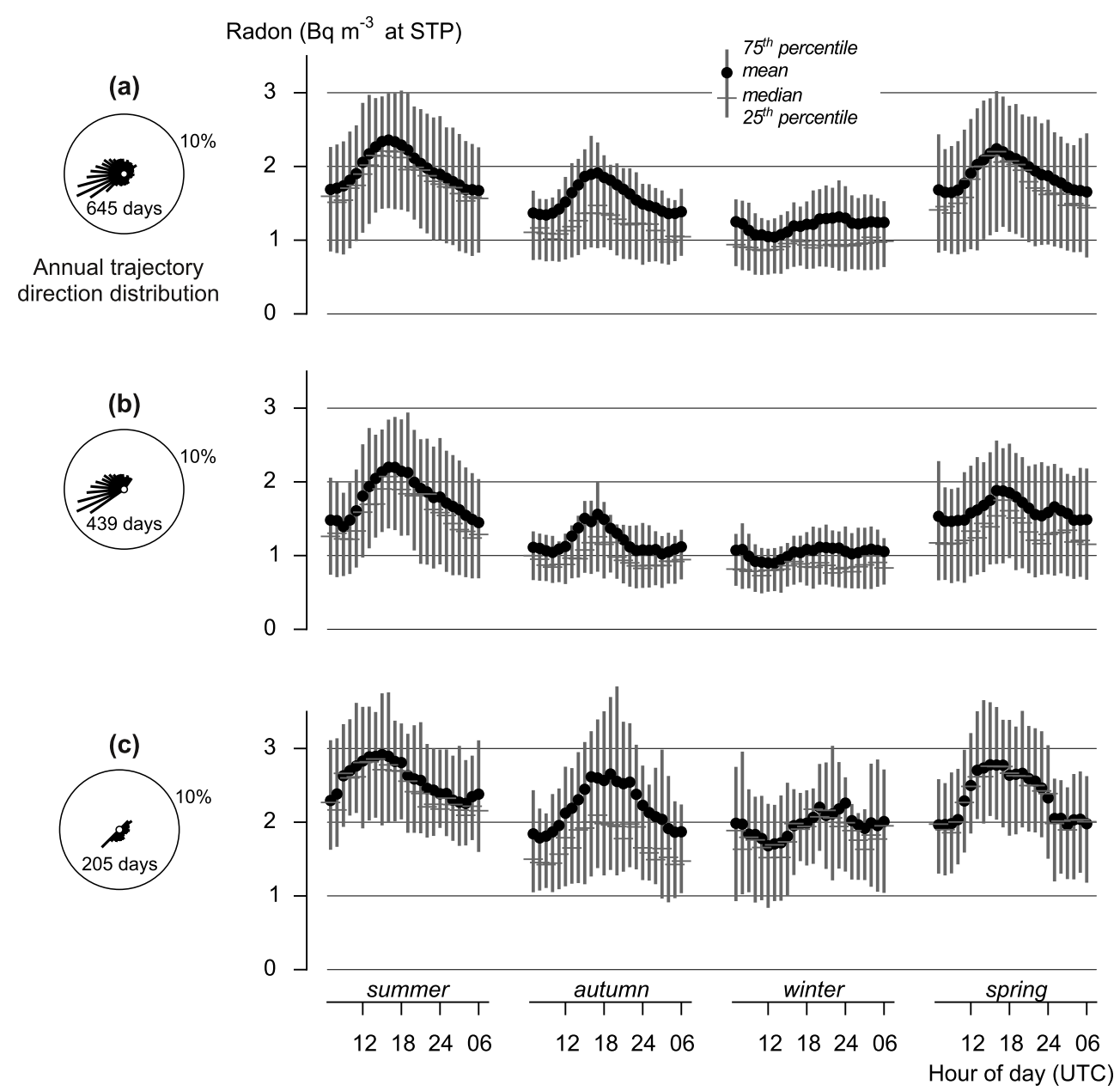

Figure 4. Radon diurnal and seasonal cycle. The plots show the mean (dot), median (horizontal bar) and 25th-75th percentile range (vertical bar) of each bin. The synoptic-scale wind direction is calculated from the back-trajectory position at a distance of $61 \mathrm{~km}$ (the distance between Bern and Jungfraujoch). Plots in (a) show all directions, in (b) show air arriving from the north-western side of the Alps (which are aligned south-west to north-east), and in (c) show air arriving from the south-east after passing over the full width of the Alps.

\section{Results and discussion}

\subsection{Characteristics of the radon distribution}

Seasonal radon composites are shown in Fig. 4, including separate plots for trajectories arriving from either side of the Alps. Over the 2-year period, hourly radon measurements were available for $88 \%$ of the time, allowing $77 \%$ of the days to be ranked for the likely presence of anabatic flows. This difference arises because days with data gaps in excess of $3 \mathrm{~h}$ were excluded from further analysis. Missing data were spread throughout the year, with the result that the data gaps do not introduce a seasonal bias.

Composite mean radon values, as shown in Fig. 4, are sensitive to time of day, season, and wind direction. Furthermore, the average strength of the diurnal cycle changes with wind direction.
Months other than winter show a diurnal cycle which is characteristic of anabatic mountain winds, with higher radon concentrations in the afternoon. In winter, the peak-to-peak amplitude is smaller than the distribution spread and there is no evidence of anabatic winds. Instead of an afternoon peak, there is a discernible minimum during the daytime at 12:00 UTC.

Low radon concentrations have been associated with a lull period between the cessation of katabatic flow and the onset of anabatic flow on Mauna Loa (Chambers et al., 2013), but the timing is wrong for an explanation of the 12:00 UTC minimum in our winter data. The timing of the radon minimum at Jungfraujoch in winter corresponds with the minimum in composite wind speed (not shown), indicating that the radon minimum is due to lower average wind speeds and therefore less vertical transport from the interaction of synoptic winds with terrain. 
For these two years, composites for the months OctoberMarch (not shown) had a negligible diurnal cycle, consistent with the absence of anabatic winds.

Radon concentrations are higher on average, about double, when the air mass arrives from the south-east. A partial explanation could be higher radon emissions south-east of the Alps, which are reported by López-Coto et al. (2013). But emissions are similar across the Alps in the results of Szegvary et al. (2009) and Manohar et al. (2013). Furthermore, near-surface radon concentrations in Milan (Sesana et al., 2003) and northern Italy (Galmarini, 2006) are similar to our measurements from Bern, making this explanation doubtful.

A more likely explanation is that air masses arriving from the south-east have had more contact with land. To reach the station from the south-east, air must cross the full width of the Alps, whereas air arriving from the north-west is unobstructed. Adding to the contrast, atmospheric conditions may be more favourable for vertical transport during periods of south-east flow; for instance, Föhn winds arrive from the south more frequently than from the north (Zellweger et al., 2003). Determining the relative importance of these factors is outside the scope of the present study, but we take wind direction effects into account by restricting our attention to north-west fetch in some of the analyses which follow.

In Fig. 5, composite diurnal cycles are generated according to the anabatic rank, which results in grouping together days with similar diurnal cycles. Although each of these composites are generated from a similar number of samples to those of Fig. 4, the diurnal cycle explains a large fraction of the concentration variance for low-rank days, as seen by the narrow spread in hourly distributions relative to the size of the diurnal peak.

To place the Jungfraujoch radon measurements in context, the observations at Bern, $3 \mathrm{~km}$ below on the Swiss Plateau, are also shown in this plot. For the highest ranking composite, adiabatically ranked days 1-50, the daytime peak radon concentration at Jungfraujoch equals the daytime minimum value measured at Bern. This suggests that the two sites sample the same air mass on low-rank days.

The availability of radon measurements from Bern make it tempting to use the difference in afternoon radon concentration, $\Delta \mathrm{Rn}=\mathrm{Rn}_{\mathrm{B}}-\mathrm{R} \mathrm{n}_{\mathrm{JFJ}}$ proportional to the mean radon gradient between Bern and Jungfraujoch, as an indicator of mixing strength. From Fig. 5 it is clear that $\Delta R n$ is close to zero on days ranked 1-50 and is thus a good indicator of strong vertical transport. It is less clear that, when nonzero, the magnitude of $\Delta \mathrm{Rn}$ relates directly to mixing strength. During times when the air masses are only weakly coupled, the first-order influences on $\Delta \mathrm{Rn}$ are the factors which control $R n_{B}$, because $R n_{B} \gg R n_{J F J}$ and therefore $\Delta R n \sim R n_{B}$. These factors include the boundary-layer mixing depth at Bern, $h$. On the other hand, the radon concentration measured at Jungfraujoch is primarily influenced by the long-term history of contact with the ground (the land fetch). Although high values of $\mathrm{Rn}_{\mathrm{JFJ}}$ may be associated with deep mixing and vertical transport, the radon concentration is directly related to the decay-weighted integral of the measurement footprint, defined formally by Lin et al. (2003), for example. For trace gases at Jungfraujoch, details of the measurement footprint are likely to be of more significance than the turbulent mixing strength.

The diurnal cycle at Bern also exhibits a weak but systematic dependence on anabatic rank, with the largest peak-topeak range on days ranked 1-50 (Fig. 5). This can be explained by assuming that, at Bern, the mixing height $h$ is the main driver of radon variability. A large peak-to-peak range in $h$ is consistent with clear-sky conditions in summer, which is also when anabatic winds are most energetic.

The lower-ranked composites are associated with an increasing separation between Bern and Jungfraujoch until the diurnal cycle disappears from the Jungfraujoch data on about the 200th day (Fig. 5). After this point, in the absence of a diurnal signal, the ranking algorithm sorts days from lowto-high intra-day variability - by accident rather than by design. We see that days with larger variability are more likely to have higher mean values at Jungfraujoch; the composite of the last days selected by the algorithm (days 511580 ) is without a significant diurnal cycle, but the mean radon concentration is high $\left(1.94 \mathrm{~Bq} \mathrm{~m}^{-3} \mathrm{STP}\right.$ compared with $1.03 \mathrm{~Bq} \mathrm{~m}^{-3} \mathrm{STP}$ for days 200-249). As well as having a high variability, the hourly distributions of Jungfraujoch radon overlap with the daytime minimum seen in Bern. High radon concentrations mean that these days are associated with recent vertical transport, sometimes resulting in radon concentrations at Jungfraujoch as high as those in the boundary layer at Bern, but the absence of a composite diurnal cycle means that vertical transport is not driven by solar forcing. On these days, vertical transport is most likely the result of synoptic-scale winds interacting with terrain.

Compared with a ranking based on fitting a sinusoid to daily concentration fluctuations (Gallagher et al., 2011), our method is in good agreement overall. For the 100 most anabatic days according to our method, only one was nonanabatic according to a sinusoid fit. For the days ranked 100200, however, 27 were classified as non-anabatic by the sinusoid method. For the days which differed, those classified as anabatic by our method typically had a rapid morning increase in radon without an evening drop, consistent with an anabatic event followed by stagnation of the large-scale flow. The opposite held true for anabatic days according to the sinusoid fit, which were characterised by flat concentrations throughout the day followed by a rapid drop during the night - thus fitting a sinusoid reasonably well, despite being unlikely to result from anabatic mountain winds. In summary, our ranking method appears to be superior to the sinusoid method, but mainly when anabatic flows are weak. As a consequence, the difference between the methods is likely to be of only minor significance for the interpretation of atmospheric composition observations, but might be more important for other studies. 


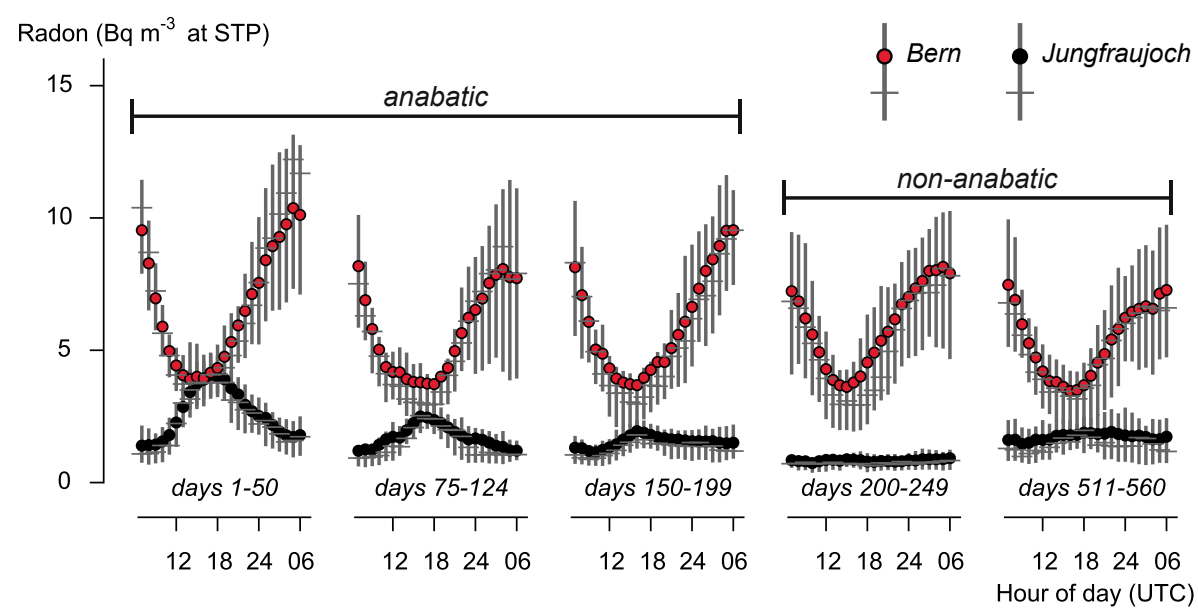

Figure 5. The 50-day diurnal composite radon concentration by anabatic rank. The air mass is fully mixed between Bern and Jungfraujoch during the afternoon on days with a rank of 50 or less; days with a rank of 200 or more are considered to be unaffected by anabatic winds. The symbols have the same meaning as in Fig. 4.

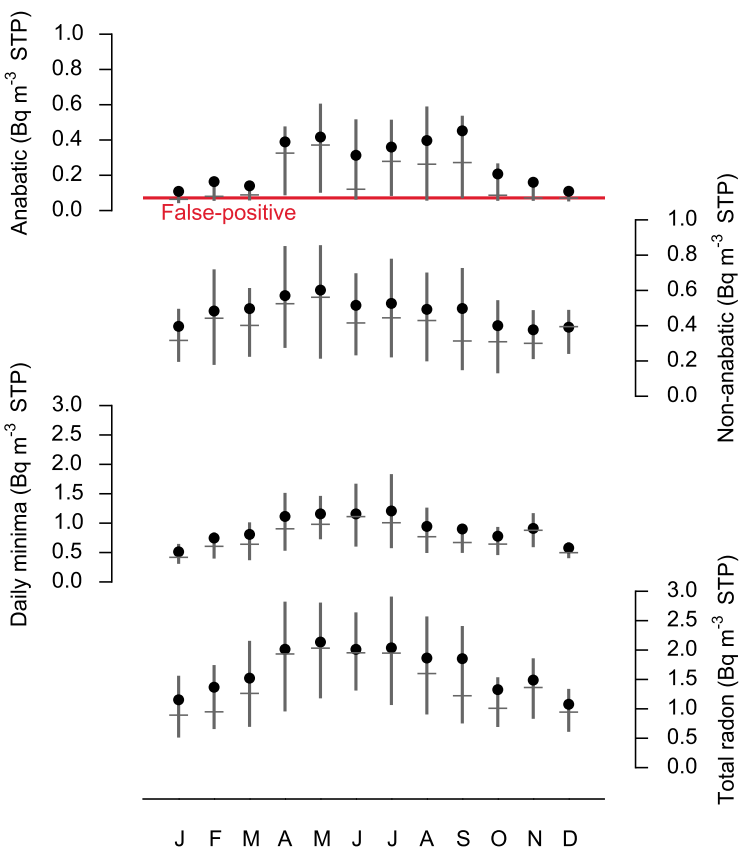

Figure 6. Seasonal cycle of decomposed daily radon concentration using the definitions shown in Fig. 2. The annual mean falsepositive contribution is included on the anabatic plot, showing that anabatic flows are detected with confidence during the months of April-September. The symbols have the same meaning as in Fig. 4.

Figure 6 shows the decomposed seasonal cycle. Anabatic radon, namely radon arriving at Jungfraujoch as a result of thermally induced transport, is close to the expected falsepositive concentration in October through to March, meaning that thermally driven transport is absent during these months. This is consistent with the negligible diurnal cycles we observed over this period and in close agreement with Forrer et al. (2000), who observed weak diurnal cycles of carbon monoxide and specific humidity in autumn and winter.

Non-anabatic radon shows a weak seasonal cycle. While this may be a real phenomenon associated with changes in air-mass fetch, the decomposition method is only approximate, and cannot prevent a proportion of anabatic radon leaking into the non-anabatic classification. Our results are therefore consistent with there being an absent or weak seasonal cycle of vertical transport by non-anabatic flows. Over these two years, the monthly mean wind speed was lower in summer, typically $5 \mathrm{~m} \mathrm{~s}^{-1}$ compared to $7 \mathrm{~m} \mathrm{~s}^{-1}$ during winter, indicating the potential for stronger non-anabatic transport in winter, contrary to Fig. 6.

It is also possible that the apparent correspondence between the mean anabatic and non-anabatic concentrations in Fig. 6 is attributable to approximations in the method. Another way of approaching the issue is to consider the magnitude of the seasonal cycle directly. Radon is higher in summer by a factor of two, compared with winter. Knowing that anabatic flows are absent in winter, assuming that the nonanabatic vertical transport is constant throughout the year, and neglecting any seasonal changes in radon emissions or land fetch leads to the conclusion that in summer half of the radon we measure is transported to Jungfraujoch by anabatic processes and half by non-anabatic processes.

The monthly distributions of daily minimum radon concentration also show a seasonality, with higher concentrations in summer. A simple explanation exists if the influence of anabatic flow conditions persists through to the following day. Figure 7 shows a multi-day composite radon concentration, constructed by selecting periods when a day with anabatic influence is followed by two days without. Data where back-trajectories indicated south-east fetch were excluded to avoid the effect of any systematic wind shifts associated with a change from anabatic to non-anabatic condi- 


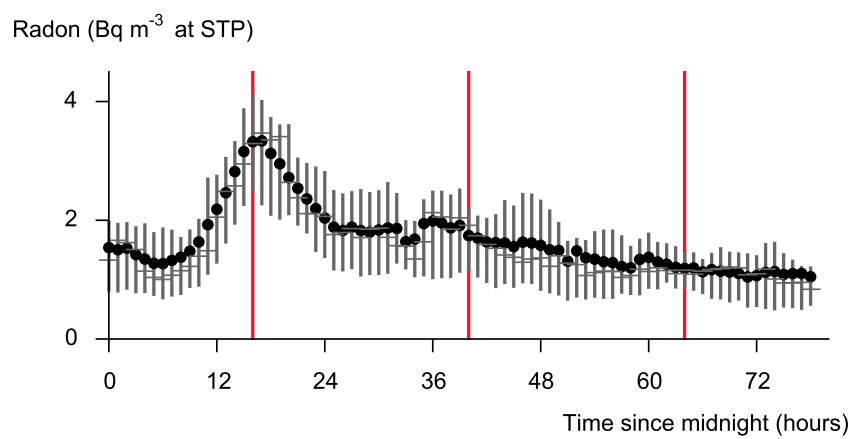

Figure 7. The 3-day radon composites ( $\sim 19$ samples per bin) of one anabatic day followed by two non-anabatic days, selecting north-west fetch. Red lines show the median peak radon concentration, $24 \mathrm{~h}$ after, and $48 \mathrm{~h}$ after. The symbols have the same meaning as in Fig. 4.

tions. After an anabatic flow event, mean and median radon concentration remain elevated for up to $48 \mathrm{~h}$ after the anabatic peak. Though dropping rapidly from the afternoon peak, night-time radon concentrations remain elevated after an anabatic event compared with concentrations during the previous night.

\subsection{Comparison with other indicators of upslope winds}

Radon's physical properties and source distribution make it almost ideal as a passive tracer of land influence. On the other hand, it is not as widely observed as some other tracers or aerosol parameters. In particular the water vapour mixing ratio, $r$, is a convenient tracer because of widespread measurements and usually easily detectable increases in moisture in the lower free troposphere under conditions with anabatic flows (Henne et al., 2005).

Figure 8 shows how radon and water vapour compare as indicators of anabatic flow. Assuming the radon technique is accurate, anabatic flow occurs on around $40 \%$ of days (Fig. 8a). An approach based on water vapour increases this estimate to $50 \%$ (Fig. 8b). Two other options which we examined, the aerosol scattering coefficient and carbon monoxide concentration (Figs. 8c and d), detected roughly half as many anabatic days, whereas $\mathrm{NO}_{\mathrm{y}}$ led to a similar proportion of anabatic days to radon (Fig. 8e) but with radon showing more contrast between the two classes.

We now examine our claim that radon is more representative of surface influence than $r$. In order to do this we take observed daily temperatures (the gridded E-OBS data (Haylock et al., 2008)), and extract a contingency table of daily maximum temperature anomalies depending on the classification according to radon and moisture, shown in Fig. 9. This is an independent test of the ranking method, based on the premise that anabatic mountain winds are more common on warm days.

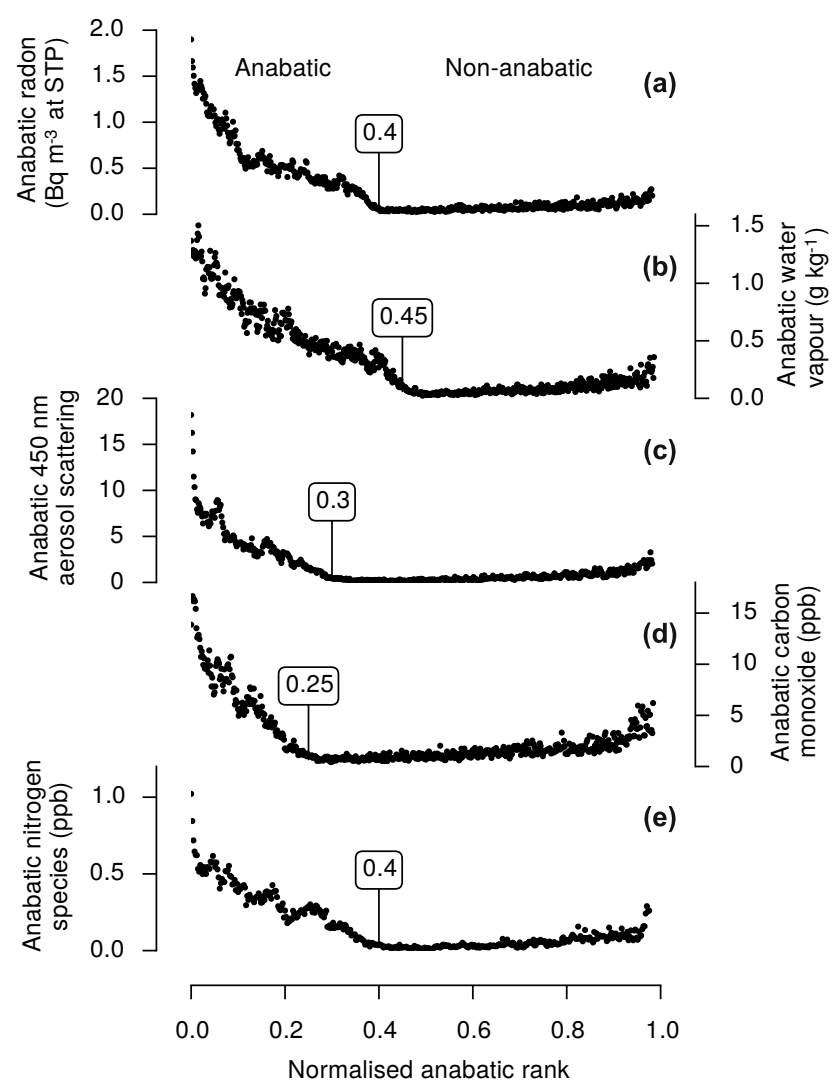

Figure 8. The anabatic contribution, meaning the daily mean concentration due to anabatic flows, of several tracers as functions of the anabatic rank normalised by total number of observation days. The minimum in the anabatic concentration marks the boundary between anabatic days, with lower anabatic rank, and non-anabatic days.

Rather than showing that one method is drastically better than the other, the main conclusion from Fig. 9 is that a more accurate classification could come from combining both. For $71 \%$ of the time, radon and $r$ are in agreement and are associated with statistically significant changes in maximum temperature anomalies. Days classified as anabatic are warmer than average over a large part of Europe; non-anabatic days are cooler over the same region.

When the tracers disagree, there is a much weaker signal in observed temperatures. Days which have been classified as anabatic according to $r$ but not radon are not significantly different from usual, so are probably false positives caused by unrelated fluctuations in $r$.

There are fewer days when radon, but not $r$, leads to an anabatic classification. On these days, there is a small (statistically significant) warm region south-east of Jungfraujoch, which also happens to be a region without significant changes in temperature for other cases. This seems to rule out all of these being false positives, though it is likely that some are. On days when $r$ fails to detect anabatic flows, confound- 
(a) Both anabatic

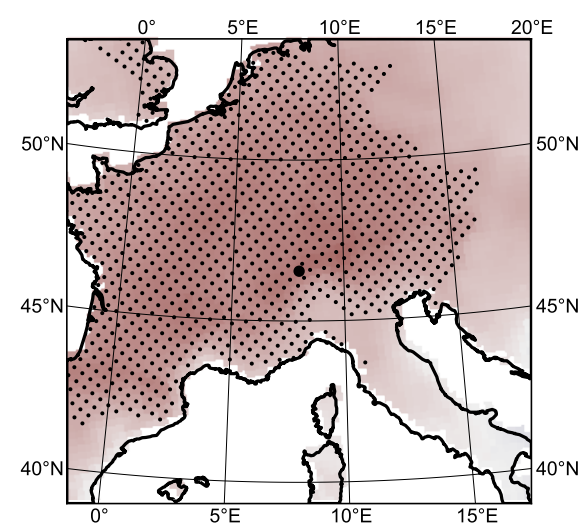

(c) Radon anabatic

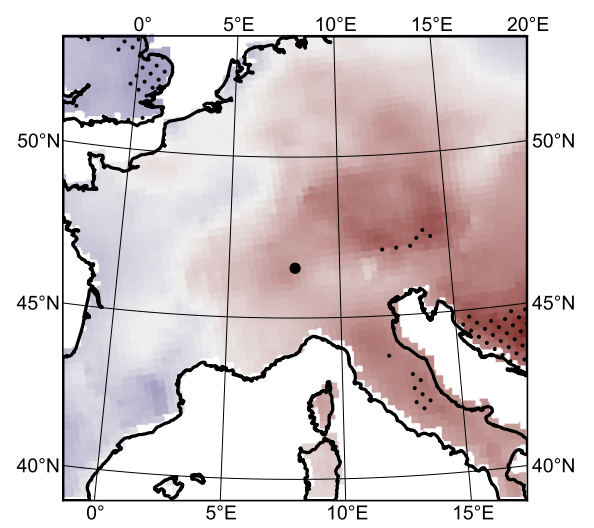

(b) Moisture anabatic

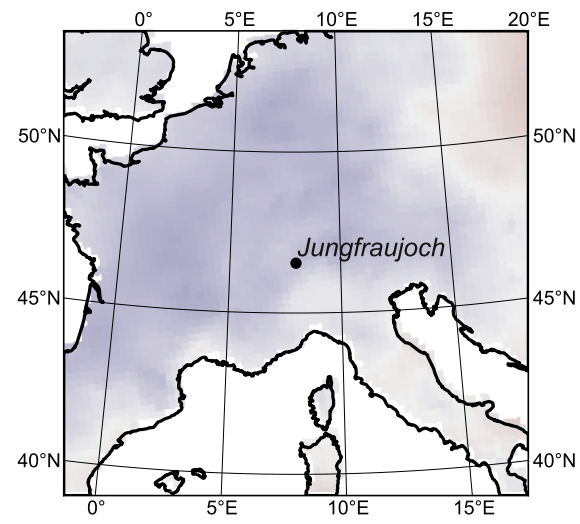

(d) Both non-anabatic

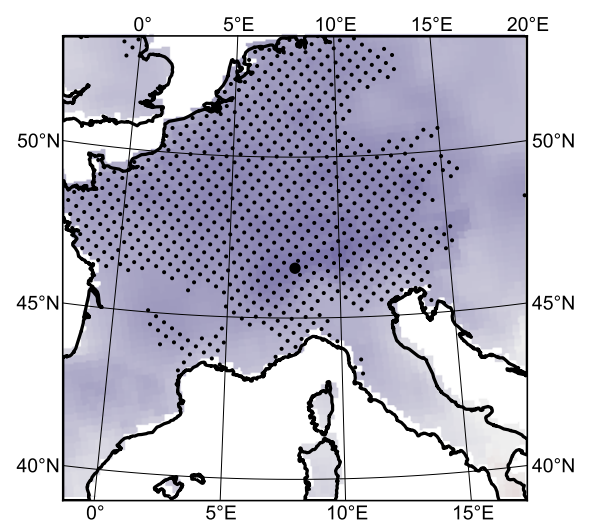

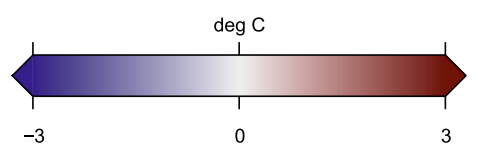

Figure 9. Daily maximum temperature anomalies for months with anabatic flows (April-September, inclusive) defined as the mean of each group minus the mean anomaly for all days with data available. The groups are: (a) days which are anabatic according to both radon and $r$, 140 samples; (b) anabatic days according to $r$ but not radon, 68 samples; (c) anabatic days according to radon but not $r$, 73 samples; and (d) non-anabatic days according to both tracers, 82 samples. The stippled region indicates a statistically significant difference between the group mean and the full population at the $95 \%$ confidence level according to Welch's $t$ test (Press et al., 2007; Welch, 1947). Data are gridded observations from E-OBS (Haylock et al., 2008).

ing factors include moisture's higher background variability compared with radon, which is a result of different sinks and sources.

In contrast to the binary anabatic/non-anabatic classification, a direct comparison of rank between radon and $r$ leads to poor agreement. In light of this, we avoid relying on the numerical rank in the analyses which follow and instead focus on the classification.

Following a different approach entirely, previous investigations (Collaud Coen et al., 2011; Lugauer et al., 1998) have found that circulation-pattern classifications (Huth et al., 2008) are useful for explaining the occurrence of anabatic conditions at Jungfraujoch. Many schemes have been developed (Demuzere et al., 2011; Philipp et al., 2010); for com- parison with the radon-based method we selected the CAP9 scheme, a nine-class objective scheme based on mean sea level pressure in a domain centred on the Alps and implemented by MeteoSwiss (MeteoSwiss, 2012). We used this scheme for two reasons: it has few classes, allowing for more robust statistics in our relatively short data set; and it has been demonstrated to perform well in the Alpine region for precipitation (Schiemann and Frei, 2010). When compared with our radon-based classification, we found radon concentration was weakly associated with circulation type, but circulation class was not a good predictor of anabatic conditions. Similarly, Zellweger et al. (2003) found that direct atmospheric observations $\left(\mathrm{NO}_{\mathrm{y}}\right.$, aerosol and humidity) were a better pre- 


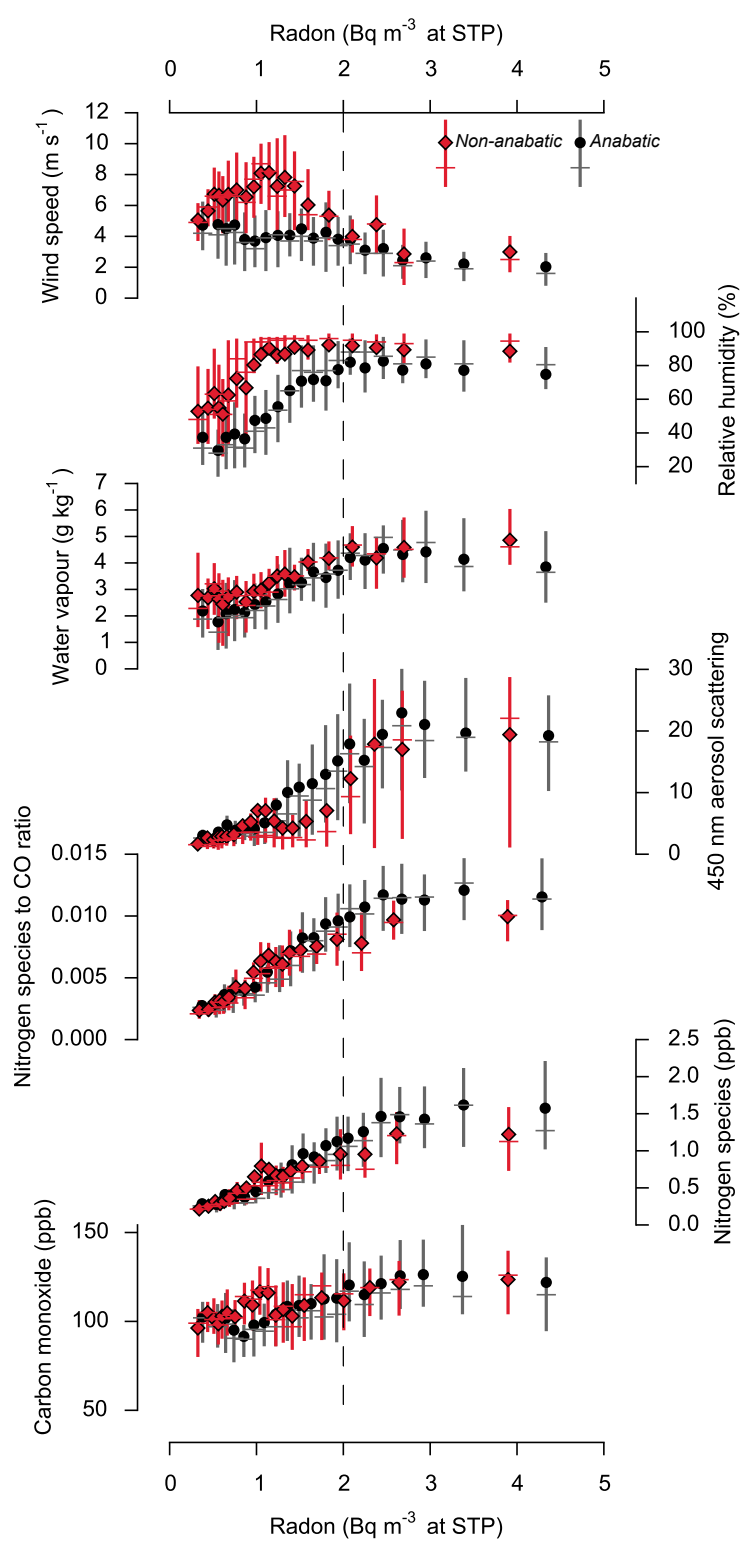

Figure 10. Hourly observations of tracer and meteorological parameters binned according to radon concentration for anabatic and non-anabatic days. The comparison is restricted to the months when anabatic flows are detected (April-September); hours when the air mass arrives from the north-west; and when the radon and moisture methods agree on the anabatic/non-anabatic classification. For moderate radon concentration, anabatic days are calmer and dryer and aerosols are more abundant. The symbols have the same meaning as in Fig. 4.

dictor of thermally driven vertical transport than circulation classification according to the Alpine Weather Statistics.

\subsection{Air mass characteristics}

Considering the different measurement footprint and transport mechanisms on anabatic vs. non-anabatic days, we ex- pect systematic differences in air-mass properties. To test this idea, however, we first need to account for several other effects that also influence composition: total land-surface influence, large-scale fetch and season.

To account for the total land-surface influence we bin measured parameters by a proxy: radon concentration. To eliminate the effect of different large-scale fetch regions, we restrict the comparison to trajectories arriving from the northwest. Although not shown here, radon measurements do indicate a difference in the mechanism of vertical transport for south-east back-trajectories; the radon concentration and therefore land-surface influence - increases with increasing wind speed, whereas the opposite trend holds for northwest back-trajectories. Anabatic days occur only for part of the year, so a direct comparison between anabatic and nonanabatic days would bias the anabatic data towards summer measurements. Therefore, we compare only the months from April through to September, when both anabatic and nonanabatic flows are detected.

Figure 10 shows that several parameters have an inflection or discontinuity at a radon concentration of around $2 \mathrm{~Bq} \mathrm{~m}^{-3}$ STP.

Wind speeds differ between anabatic and non-anabatic days; winds are always lower on anabatic days, and have a weak decreasing trend with increasing radon concentration. On non-anabatic days, low radon concentrations are associated with strong winds, but non-anabatic days have similar wind conditions to anabatic days for radon concentrations greater than $2 \mathrm{~Bq} \mathrm{~m}^{-3} \mathrm{STP}$. This is consistent with the anabatic and non-anabatic days being linked to different dynamical processes. On non-anabatic days with radon below $1.5 \mathrm{~Bq} \mathrm{~m}^{-3} \mathrm{STP}$, an increase in wind speed means stronger vertical transport due to the interaction between terrain and synoptic scale winds. To maintain radon concentrations above this threshold, it seems that low wind speeds are needed to prevent radon being diluted by the advection of radon-depleted free-tropospheric air.

On anabatic days the air is dryer, both in terms of relative humidity and, less dramatically, the water vapour mixing ratio, because anabatic situations are favoured by fair weather conditions. Non-anabatic days are likely to be close to saturation for radon concentrations of $1.5 \mathrm{~Bq} \mathrm{~m}^{-3} \mathrm{STP}$ or higher, so non-anabatic vertical transport is likely to be associated with clouds, which envelope the site for about $40 \%$ of the year (Andrews et al., 2011; Baltensperger et al., 1998).

On anabatic days, there is a clear correlation between radon (a proxy for surface contact) and aerosol abundances. In contrast, on non-anabatic days the median aerosol concentration is low and only weakly dependent on radon concentration (up until $2 \mathrm{~Bq} \mathrm{~m}^{-3} \mathrm{STP}$ ). In this range it is also strongly skewed, since the mean is influenced by a few highconcentration events. On non-anabatic days, it is possible to observe low aerosol concentrations at the same time as high radon. These cases might be associated with precipitation and aerosol washout. 
Like radon, the molar ratio of total reactive nitrogen species to carbon monoxide, $\left[\mathrm{NO}_{\mathrm{y}}\right] /[\mathrm{CO}]$, is used as an indicator of recent land influence (Pandey Deolal et al., 2013). Though emitted in a relatively stable ratio from pollution sources, $\mathrm{NO}_{\mathrm{y}}$ is removed faster than $\mathrm{CO}$.

For high radon concentrations, which are associated with arrival of anabatic flow at the mountain peak, $\left[\mathrm{NO}_{\mathrm{y}}\right] /[\mathrm{CO}]$ is larger on anabatic days. This suggests that closer sources might be more important on anabatic days. The difference is relatively small, however, and an alternative explanation might be that cloud processes remove $\mathrm{NO}_{\mathrm{y}}$ more quickly on non-anabatic days than on anabatic days when clouds tend to be absent.

For higher radon concentrations, above $2.5 \mathrm{~Bq} \mathrm{~m}^{-3} \mathrm{STP}$ which is the 80th percentile of the observed distribution, many of the quantities plotted in Fig. 10 are close to constant. Although this could mean that the highest radon observations are due to local emissions, these other tracers have seasonal cycles in their sources and sinks which distorts the relationship because high radon values are most common in midsummer. Accounting for the seasonal cycle in these other tracers, by applying a high-pass filter which retains fluctuations with a period of $35 \mathrm{~d}$ or less, the relationship between binned radon concentration and other land-surface tracers (for example $\mathrm{N}_{2} \mathrm{O}$, not shown, and $\mathrm{CO}$ ) continues to increase in a near-linear fashion until $5 \mathrm{~Bq} \mathrm{~m}^{-3} \mathrm{STP}$ (98.5th percentile). This suggests that local sources are not a major contributor to observed radon concentrations at Jungfraujoch.

\subsection{Radon-derived baseline}

Baseline air is characterised by undisturbed background concentrations of short-lived pollutants, though the specifics of its identification depend on the reason for study, the species in question, and the measurement site. At Jungfraujoch, measurements affected by anabatic winds or by strong nonanabatic vertical transport cannot be expected to be representative of the regional-scale free troposphere. Identifying these periods of local influence is a primary application of radon measurements, which provide an unambiguous method for defining baseline conditions. Radon has been used at sites including Mauna Loa (Chambers et al., 2013), Cape Grim (Zahorowski et al., 2013) and Jungfraujoch itself (Xia et al., 2013), and here we combine radon and aerosol measurements to examine the importance of anabatic flow detection in the context of defining a radon-derived atmospheric baseline.

In Fig. 11, which differs from Fig. 10d by including all observations, the median aerosol scattering coefficient levels out for radon concentrations below $2 \mathrm{~Bq} \mathrm{~m}^{-3} \mathrm{STP}$; for summer non-anabatic days the shoulder is present at a similar level (Fig. 10d). So baseline aerosol statistics could be computed from a radon threshold. Here we briefly discuss how this compares with other commonly used baseline definitions and examine the effect of excluding anabatic days.

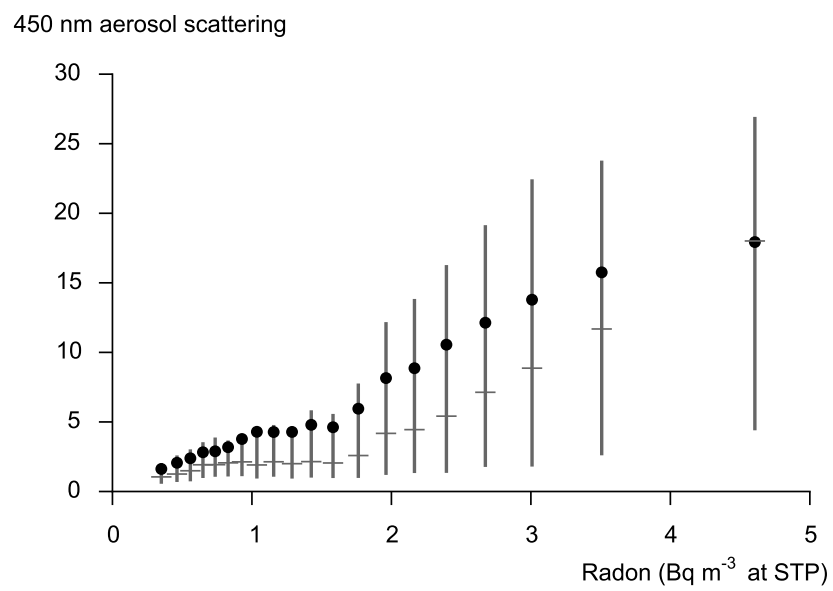

Figure 11. Aerosol scattering coefficient binned by radon concentration. Data are from all months and wind directions. The symbols have the same meaning as in Fig. 4.

The value of $2 \mathrm{~Bq} \mathrm{~m}^{-3} \mathrm{STP}$ also corresponds with the summer $\left[\mathrm{NO}_{\mathrm{y}}\right] /[\mathrm{CO}]$ ratio of 0.008 , identified by Pandey Deolal et al. (2013) as characteristic of baseline conditions (Fig. 10e). Arguably radon has an advantage in that a constant value is more appropriate year round, whereas the destruction rate of $\mathrm{CO}$ varies with season. But seasonal changes in radon emissions, which are sensitive to soil moisture and large-scale fetch, means that a seasonally varying threshold might also be preferred for radon.

The agreement between the two criteria, though indicating consistency between the tracers, is not of critical importance; any threshold is study specific and most of the plots in Fig. 10 show a continuous variation in air-mass properties rather than a step change. For instance, Xia et al. (2013) used a threshold of $0.5 \mathrm{~Bq} \mathrm{~m}^{-3}\left(\sim 0.75 \mathrm{~Bq} \mathrm{~m}^{-3} \mathrm{STP}\right)$, further limiting recent contributions from the land surface compared with the Pandey Deolal et al. (2013) criteria and approaching the observed radon concentration in oceanic baseline air at Mace Head, a few tens of $\mathrm{mBq} \mathrm{m}^{-3}$ (Biraud et al., 2000).

Figure 12 depicts monthly median values after applying several baseline definitions to the aerosol data. For some months, a $2 \mathrm{~Bq} \mathrm{~m}^{-3} \mathrm{STP}$ radon threshold may be too high to eliminate transient spikes from baseline values, though a trade-off exists between data availability and smoothness. Compared with a simple time-of-day filter (Andrews et al., 2011), a radon-based definition results in a smoother seasonality of baseline values while retaining a similar amount of data. In this case, the choice of baseline definition can make a nontrivial difference.

The use of a $2 \mathrm{~Bq} \mathrm{~m}^{-3}$ STP threshold can be further refined, either by eliminating anabatic days or by choosing a lower value. The elimination of anabatic days, combined with a threshold of $2 \mathrm{~Bq} \mathrm{~m}^{-3} \mathrm{STP}$, has only a minor effect. A peak is removed from the baseline for April 2011, implying that unusually active mountain winds were responsible 


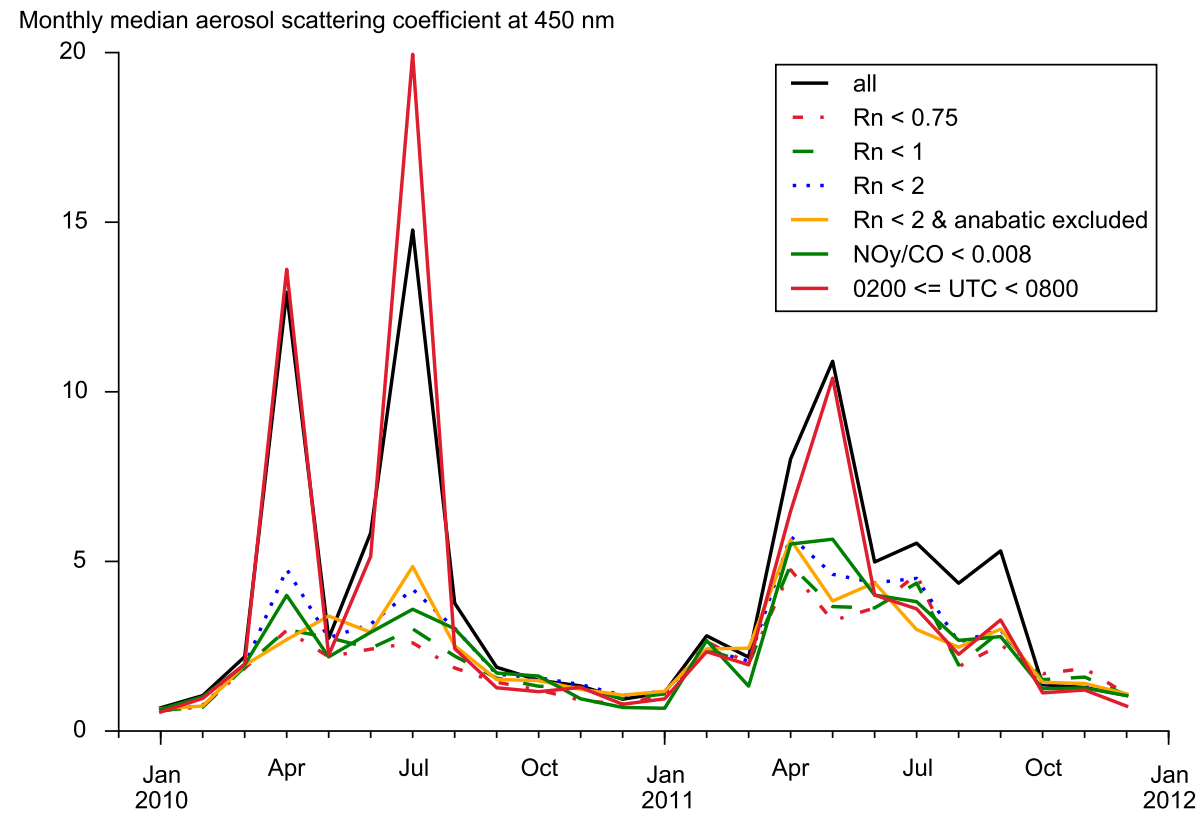

Figure 12. Monthly median aerosol scattering coefficient from different selection criteria: all data; radon concentration less than 0.75 , 1 , and $2 \mathrm{~Bq} \mathrm{~m}^{-3} \mathrm{STP}$ (the latter with anabatic days excluded); chemical filter based on [NOy $]$ / [CO] ratio (Pandey Deolal et al., 2013); time-of-day filter. The time-of-day filter is similar to Andrews et al. (2011), keeping data measured during a time window of 03:00-09:00 local time, but we show the median value instead of the mean.

for the higher radon concentrations seen that month, but otherwise it is more effective, in terms of the number of observations retained, to reduce the threshold. For sufficiently low radon thresholds, the imposition of an anabatic-day criterion is redundant, since radon is usually high on anabatic days. For thresholds of 1 or $0.75 \mathrm{~Bq} \mathrm{~m}^{-3} \mathrm{STP}$, the baseline aerosol signal converges, especially during winter, despite making a relatively large difference to data availability.

From these considerations, a baseline radon threshold of $1 \mathrm{~Bq} \mathrm{~m}^{-3}$ STP works well for continuous aerosol measurements, but a reasonable choice could easily lie in the range $0.75-2 \mathrm{~Bq} \mathrm{~m}^{-3} \mathrm{STP}$, depending on the desired remoteness of land surface influence.

\section{Conclusions}

Radon - to a good approximation - is a direct indicator of land influence. From our analysis of the 2010-2011 hourly radon concentration at Jungfraujoch, the primary outcome was a classification of each day as affected, or unaffected, by thermally driven or anabatic mountain winds as well as a less robust measure of how strong the influence was. On the most strongly affected days, matching radon concentrations at Bern and Jungfraujoch were taken as evidence of relatively unperturbed transport of boundary-layer air from the Swiss Plateau to Jungfraujoch.

Anabatic winds are likely to be most prominent during conditions of clear skies and low winds. We found that an- abatic days had, on average, higher daily maximum temperatures over central Europe, lower winds at Jungfraujoch, and weaker wet scavenging of aerosols. The effect on temperature was stronger when absolute humidity was used in addition to radon for classification, indicating that a more robust classification is achieved when using more than one tracer.

During periods of high relative humidity and strong winds at Jungfraujoch, high radon concentrations were sometimes observed, indicative of strong or recent land influence. However, these days lacked the characteristic diurnal cycle of anabatic flows, resulting in their classification as non-anabatic, and were most likely the result of dynamic influences (e.g. Föhn winds).

For defining the baseline aerosol scattering coefficient, or in other words the unperturbed free-tropospheric background, we showed that a radon threshold in the range of 1$2 \mathrm{~Bq} \mathrm{~m}^{-3} \mathrm{STP}$ is appropriate and that the monthly median is relatively insensitive to the radon threshold within this range. Refining the definition by excluding anabatic days was of no additional benefit. In other words, the potential land-surface influence, as characterised by the measured radon concentration, is of primary importance and the mechanism less so.

With the continuing operation of the Jungfraujoch radon detector, which provides sensitive quantitative measurements of the radon concentration, we anticipate that these data will be useful in other observational and modelling studies. Future studies could examine the effect of spatially and temporally varying radon emissions, overcoming one limitation of 
the present investigation. Instructions for accessing the radon data are at http://www.radon.unibas.ch/.

Acknowledgements. We acknowledge the E-OBS dataset from the EU-FP6 project ENSEMBLES (http://ensembles-eu. metoffice.com) and the data providers in the ECA\&D project (http://www.ecad.eu). The Swiss National Air Pollution Monitoring Network (NABEL) is operated by Empa in collaboration with the Swiss Federal Office for the Environment. We thank MeteoSwiss for the provision of meteorological date and weather type classifications and for the support of Paul Scherrer Institute's long-term aerosol monitoring programme. We also thank the international data repositories for access to chemical and meteorological data (from the World Data Centre for Greenhouse Gases, http://ds.data.jma.go.jp, and EBAS, http://ebas.nilu.no/), in particular measurements performed by Empa and weather-type classifications provided by MeteoSwiss. We thank the International Foundation High Alpine Research Stations Jungfraujoch and Gornergrat (HFSJG) for making it possible for us to carry out our measurements at the High Alpine Research Station Jungfraujoch. We are grateful to Markus Leuenberger and Peter Nyfeler from the Climate and Environmental Physics Division, Physics Institute, University of Bern, for hosting and supporting maintenance of our detector in Bern.

Edited by: L. Zhang

\section{References}

Andrews, E., Ogren, J., Bonasoni, P., Marinoni, A., Cuevas, E., Rodríguez, S., Sun, J., Jaffe, D., Fischer, E., Baltensperger, U., Weingartner, E., Coen, M. C., Sharma, S., Macdonald, A., Leaitch, W., Lin, N.-H., Laj, P., Arsov, T., Kalapov, I., Jefferson, A., and Sheridan, P.: Climatology of aerosol radiative properties in the free troposphere, Atmos. Res., 102, 365-393, doi:10.1016/j.atmosres.2011.08.017, 2011.

Appenzeller, C., Begert, M., Zenklusen, E., and Scherrer, S. C.: Monitoring climate at Jungfraujoch in the high Swiss Alpine region, Sci. Total Environ., 391, 262-268, doi:10.1016/j.scitotenv.2007.10.005, 2008.

ARL: HYSPLIT - Hybrid Single Particle Lagrangian Integrated Trajectory model, available at: http://www.arl.noaa.gov/ (last access: 27 March 2013), 2013.

Baltensperger, U., Schwikowski, M., Jost, D., Nyeki, S., Gäggeler, H., and Poulida, O.: Scavenging of atmospheric constituents in mixed phase clouds at the high-alpine site Jungfraujoch part I: Basic concept and aerosol scavenging by clouds, Atmos. Environ., 32, 3975-3983, doi:10.1016/S1352-2310(98)00051-X, 1998.

Balzani Lööv, J. M., Henne, S., Legreid, G., Staehelin, J., Reimann, S., Prévôt, A. S. H., Steinbacher, M., and Vollmer, M. K.: Estimation of background concentrations of trace gases at the Swiss Alpine site Jungfraujoch (3580 m a.s.1.), J. Geophys. Res., 113, D22305, doi:10.1029/2007JD009751, 2008.

Biraud, S., Ciais, P., Ramonet, M., Simmonds, P., Kazan, V., Monfray, P., O’Doherty, S., Spain, T. G., and Jennings, S. G.: European greenhouse gas emissions estimated from continuous atmospheric measurements and radon 222 at Mace Head, Ireland,
J. Geophys. Res., 105, 1351-1366, doi:10.1029/1999JD900821, 2000.

Brooks, B.-G. J., Desai, A. R., Stephens, B. B., Bowling, D. R., Burns, S. P., Watt, A. S., Heck, S. L., and Sweeney, C.: Assessing filtering of mountaintop $\mathrm{CO}_{2}$ mole fractions for application to inverse models of biosphere-atmosphere carbon exchange, Atmos. Chem. Phys., 12, 2099-2115, doi:10.5194/acp-12-20992012, 2012.

Calvert, J. G.: Glossary of atmospheric chemistry terms (Recommendations 1990), Pure Appl. Chem., 62, 2167-2219, doi:10.1351/pac199062112167, 1990.

Campana, M., Li, Y., Staehelin, J., Prevot, A. S., Bonasoni, P., Loetscher, H., and Peter, T.: The influence of south foehn on the ozone mixing ratios at the high alpine site Arosa, Atmos. Environ., 39, 2945-2955, doi:10.1016/j.atmosenv.2005.01.037, 2005.

Chambers, S., Williams, A. G., Zahorowski, W., Griffiths, A., and Crawford, J.: Separating remote fetch and local mixing influences on vertical radon measurements in the lower atmosphere, Tellus B, 63, 843-859, doi:10.1111/j.1600-0889.2011.00565.x, 2011.

Chambers, S. D., Zahorowski, W., Williams, A. G., Crawford, J., and Griffiths, A. D.: Identifying tropospheric baseline air masses at Mauna Loa Observatory between 2004 and 2010 using Radon222 and back trajectories, J. Geophys. Res.-Atmos., 118, 9921004, doi:10.1029/2012JD018212, 2013.

Chevillard, A., Ciais, P., Karstens, U., Heimann, M., Schmidt, M., Levin, I., Jacob, D., Podzun, R., Kazan, V., Sartorius, H., and Weingartner, E.: Transport of ${ }^{222} \mathrm{Rn}$ using the regional model REMO: a detailed comparison with measurements over Europe, Tellus B, 54, 850-871, doi:10.1034/j.1600-0889.2002.01339.x, 2002.

Collaud Coen, M., Weingartner, E., Furger, M., Nyeki, S., Prévôt, A. S. H., Steinbacher, M., and Baltensperger, U.: Aerosol climatology and planetary boundary influence at the Jungfraujoch analyzed by synoptic weather types, Atmos. Chem. Phys., 11, 5931-5944, doi:10.5194/acp-11-5931-2011, 2011.

Cozic, J., Verheggen, B., Weingartner, E., Crosier, J., Bower, K. N., Flynn, M., Coe, H., Henning, S., Steinbacher, M., Henne, S., Collaud Coen, M., Petzold, A., and Baltensperger, U.: Chemical composition of free tropospheric aerosol for $\mathrm{PM}_{1}$ and coarse mode at the high alpine site Jungfraujoch, Atmos. Chem. Phys., 8, 407-423, doi:10.5194/acp-8-407-2008, 2008.

Cui, J., Deolal, S. P., Sprenger, M., Henne, S., Staehelin, J., Steinbacher, M., and Nédélec, P.: Free tropospheric ozone changes over Europe as observed at Jungfraujoch (1990-2008): an analysis based on backward trajectories, J. Geophys. Res., 116, D10304, doi:10.1029/2010JD015154, 2011.

De Wekker, S. F. J., Steyn, D. G., and Nyeki, S.: A comparison of aerosol-layer and convective boundary-layer structure over a mountain range during STAAARTE '97, Bound.-Lay. Meteorol., 113, 249-271, doi:10.1023/B:BOUN.0000039371.41823.37, 2004.

Demuzere, M., Kassomenos, P., and Philipp, A.: The COST733 circulation type classification software: an example for surface ozone concentrations in Central Europe, Theor. Appl. Climatol., 105, 143-166, doi:10.1007/s00704-010-0378-4, 2011.

Draxler, R. and Hess, G.: Description of the HYSPLIT-4 Modeling System, Tech. Rep. ARL-224, NOAA, Silver Spring, Maryland, 1998. 
Drobinski, P., Steinacker, R., Richner, H., Baumann-Stanzer, K., Beffrey, G., Benech, B., Berger, H., Chimani, B., Dabas, A., Dorninger, M., Dürr, B., Flamant, C., Frioud, M., Furger, M., Gröhn, I., Gubser, S., Gutermann, T., Häberli, C., HällerScharnhost, E., Jaubert, G., Lothon, M., Mitev, V., Pechinger, U., Piringer, M., Ratheiser, M., Ruffieux, D., Seiz, G., Spatzierer, M., Tschannett, S., Vogt, S., Werner, R., and Zängl, G.: Föhn in the Rhine Valley during MAP: a review of its multiscale dynamics in complex valley geometry, Q. J. Roy. Meteor. Soc., 133, 897-916, doi:10.1002/qj.70, 2007.

Feichter, J. and Crutzen, P. J.: Parameterization of vertical tracer transport due to deep cumulus convection in a global transport model and its evaluation with ${ }^{222}$ Radon measurements, Tellus B, 42, 100-117, doi:10.1034/j.1600-0889.1990.00011.x, 1990.

Folini, D., Ubl, S., and Kaufmann, P.: Lagrangian particle dispersion modeling for the high Alpine site Jungfraujoch, J. Geophys. Res., 113, D18111, doi:10.1029/2007JD009558, 2008.

Forrer, J., Rüttimann, R., Schneiter, D., Fischer, A., Buchmann, B., and Hofer, P.: Variability of trace gases at the high-Alpine site Jungfraujoch caused by meteorological transport processes, J. Geophys. Res.-Atmos., 105, 12241-12251, doi:10.1029/1999JD901178, 2000.

Furger, M.: The radiosoundings of Payerne: Aspects of the synoptic-dynamic climatology of the wind field near mountain ranges, Theor. Appl. Climatol., 45, 3-17, doi:10.1007/BF00865989, 1992.

Gäggeler, H., Jost, D., Baltensperger, U., Schwikowski, M., and Seibert, P.: Radon and thoron decay product and ${ }^{210} \mathrm{~Pb}$ measurements at Jungfraujoch, Switzerland, Atmos. Environ., 29, 607616, doi:10.1016/1352-2310(94)00195-Q, 1995.

Gallagher, J. P., McKendry, I. G., Macdonald, A. M., and Leaitch, W. R.: Seasonal and diurnal variations in aerosol concentration on Whistler Mountain: boundary layer influence and synopticscale controls, J. Appl. Meteorol. Climatol., 50, 2210-2222, doi:10.1175/JAMC-D-11-028.1, 2011.

Gallagher, J. P., McKendry, I. G., Cottle, P. W., Macdonald, A. M., Leaitch, W. R., and Strawbridge, K.: Application of lidar data to assist airmass discrimination at the Whistler Mountaintop Observatory, J. Appl. Meteorol. Climatol., 51, 1733-1739, doi:10.1175/JAMC-D-12-067.1, 2012.

Galmarini, S.: One year of ${ }^{222} \mathrm{Rn}$ concentration in the atmospheric surface layer, Atmos. Chem. Phys., 6, 2865-2886, doi:10.5194/acp-6-2865-2006, 2006.

Griffiths, A. D., Parkes, S. D., Chambers, S. D., McCabe, M. F., and Williams, A. G.: Improved mixing height monitoring through a combination of lidar and radon measurements, Atmos. Meas. Tech., 6, 207-218, doi:10.5194/amt-6-207-2013, 2013.

Grossi, C., Arnold, D., Adame, J., López-Coto, I., Bolívar, J., de la Morena, B., and Vargas, A.: Atmospheric ${ }^{222} \mathrm{Rn}$ concentration and source term at El Arenosillo $100 \mathrm{~m}$ meteorological tower in southwest Spain, Radiat. Meas., 47, 149-162, doi:10.1016/j.radmeas.2011.11.006, 2012.

Guedalia, D., Lopez, A., Fontan, J., and Birot, A.: Aircraft Measurements of Rn-222, Aitken Nuclei and Small Ions up to $6 \mathrm{~km}$, J. Appl. Meteorol., 11, 357-365, doi:10.1175/15200450(1972)011<0357:AMORAN>2.0.CO;2, 1972.

Haiden, T.: On the pressure field in the slope wind layer, J. Atmos. Sci., 60, 1632-1635, doi:10.1175/15200469(2003)60<1632:OTPFIT>2.0.CO;2, 2003.
Haylock, M. R., Hofstra, N., Klein Tank, A. M. G., Klok, E. J., Jones, P. D., and New, M.: A European daily highresolution gridded data set of surface temperature and precipitation for 1950-2006, J. Geophys. Res., 113, D20119, doi:10.1029/2008JD010201, 2008.

Henne, S., Furger, M., Nyeki, S., Steinbacher, M., Neininger, B., de Wekker, S. F. J., Dommen, J., Spichtinger, N., Stohl, A., and Prévôt, A. S. H.: Quantification of topographic venting of boundary layer air to the free troposphere, Atmos. Chem. Phys., 4, 497 509, doi:10.5194/acp-4-497-2004, 2004.

Henne, S., Furger, M., and Prévôt, A. S. H.: Climatology of mountain venting-induced elevated moisture layers in the lee of the Alps, J. Appl. Meteorol., 44, 620-633, doi:10.1175/JAM2217.1, 2005.

Huth, R., Beck, C., Philipp, A., Demuzere, M., Ustrnul, Z., Cahynová, M., Kyselý, J., and Tveito, O. E.: Classifications of atmospheric circulation patterns, Ann. N. Y. Acad. Sci., 1146, 105-152, doi:10.1196/annals.1446.019, 2008.

Keeling, C. D., Bacastow, R. B., Bainbridge, A. E., Ekdahl, C. A., Guenther, P. R., Waterman, L. S., and Chin, J. F. S.: Atmospheric carbon dioxide variations at Mauna Loa Observatory, Hawaii, Tellus, 28, 538-551, doi:10.1111/j.2153-3490.1976.tb00701.x, 1976.

Ketterer, C., Zieger, P., Bukowiecki, N., Collaud Coen, M., Maier, O., Ruffieux, D., and Weingartner, E.: Investigation of the planetary boundary layer in the Swiss Alps using remote sensing and in situ measurements, Bound.-Lay. Meteorol., 151, 317-334, doi:10.1007/s10546-013-9897-8, 2014.

Kossmann, M., Corsmeier, U., De Wekker, S., Fiedler, F., Vögtlin, R., Kalthoff, N., Güsten, H., and Neininger, B.: Observations of handover processes between the atmospheric boundary layer and the free troposphere over mountainous terrain, Contrib. Atmos. Phys., 72, 329-350, 1999.

Lee, H. N. and Cicerone, R. J.: Vertical Diffusion in the Lower Atmosphere Using Aircraft Measurements of ${ }^{222} \mathrm{Rn}$, J. Appl. Meteorol., 36, 1262-1270, doi:10.1175/15200450(1997)036<1262:VDITLA>2.0.CO;2, 1997.

Leuenberger, $M$. and Flückiger, E.: Research at Jungfraujoch, Sci. Total Environ., 391, 169-176, doi:10.1016/j.scitotenv.2007.10.044, 2008.

Lin, J. C., Gerbig, C., Wofsy, S. C., Andrews, A. E., Daube, B. C., Davis, K. J. and Grainger, C. A.: A near-field tool for simulating the upstream influence of atmospheric observations: The Stochastic Time-Inverted Lagrangian Transport (STILT) model, J. Geophys. Res., 108, 4493, doi:10.1029/2002JD003161, 2003.

López-Coto, I., Mas, J., and Bolivar, J.: A 40-year retrospective European radon flux inventory including climatological variability, Atmos. Environ., 73, 22-33, doi:10.1016/j.atmosenv.2013.02.043, 2013.

Lothon, M., Druilhet, A., Bénech, B., Campistron, B., Bernard, S., and Saïd, F.: Experimental study of five föhn events during the Mesoscale Alpine Programme: From synoptic scale to turbulence, Q. J. Roy. Meteor. Soc., 129, 2171-2193, doi:10.1256/qj.02.30, 2003.

Lugauer, M., Baltensperger, U., Furger, M., Gäggeler, H. W., Jost, D. T., Schwikowski, M., and Wanner, H.: Aerosol transport to the high Alpine sites Jungfraujoch (3454 ma.s.1.) and Colle Gnifetti (4452 m a.s.1.), Tellus B, 50, 76-92, doi:10.1034/j.16000889.1998.00006.x, 1998. 
Lugauer, M., Baltensperger, U., Furger, M., Gäggeler, H. W., Jost, D. T., Nyeki, S., and Schwikowski, M.: Influences of vertical transport and scavenging on aerosol particle surface area and radon decay product concentrations at the Jungfraujoch (3454 m above sea level), J. Geophys. Res., 105, 19869-19879, doi:10.1029/2000JD900184, 2000.

Mahrt, L.: Momentum balance of gravity flows, J. Atmos. Sci., 39, 2701-2711, doi:10.1175/15200469(1982)039<2701:MBOGF>2.0.CO;2, 1982.

Manohar, S., Meijer, H., and Herber, M.: Radon flux maps for the Netherlands and Europe using terrestrial gamma radiation derived from soil radionuclides, Atmos. Environ., 81, 399-412, doi:10.1016/j.atmosenv.2013.09.005, 2013.

MeteoSwiss: Weather type classifications, available at: http://www.meteoswiss.admin.ch/web/en/services/data_portal/ standard_products/Weather_type_class.html (last access: 4 October 2012), 2012.

NILU: EBAS, available at: http://ebas.nilu.no/ (last access: $12 \mathrm{Au}-$ gust 2012), 2012.

Nyeki, S., Kalberer, M., Colbeck, I., Wekker, S. D., Furger, M., Gäggeler, H. W., Kossmann, M., Lugauer, M., Steyn, D., Weingartner, E., Wirth, M., and Baltensperger, U.: Convective boundary layer evolution to $4 \mathrm{~km}$ a.s.l. over high-Alpine terrain: airborne lidar observations in the Alps, Geophys. Res. Lett., 27, 689-692, doi:10.1029/1999GL010928, 2000.

Pandey Deolal, S., Brunner, D., Steinbacher, M., Weers, U., and Staehelin, J.: Long-term in situ measurements of $\mathrm{NO}_{\mathrm{x}}$ and $\mathrm{NO}_{\mathrm{y}}$ at Jungfraujoch 1998-2009: time series analysis and evaluation, Atmos. Chem. Phys., 12, 2551-2566, doi:10.5194/acp-12-25512012, 2012.

Pandey Deolal, S., Staehelin, J., Brunner, D., Cui, J., Steinbacher, M., Zellweger, C., Henne, S., and Vollmer, M. K.: Transport of PAN and $\mathrm{NO}_{\mathrm{y}}$ from different source regions to the Swiss high alpine site Jungfraujoch, Atmos. Environ., 64, 103-115, doi:10.1016/j.atmosenv.2012.08.021, 2013.

Parrish, D. D., Lamarque, J.-F., Naik, V., Horowitz, L., Shindell, D. T., Staehelin, J., Derwent, R., Cooper, O. R., Tanimoto, H., Volz-Thomas, A., Gilge, S., Scheel, H.-E., Steinbacher, M. and Fröhlich, M.: Long-term changes in lower tropospheric baseline ozone concentrations: Comparing chemistry-climate models and observations at northern midlatitudes, J. Geophys. Res. Atmos., 119, 2013JD021435, doi:10.1002/2013JD021435, 2014.

Perry, K. D., Cahill, T. A., Schnell, R. C. and Harris, J. M.: Long-range transport of anthropogenic aerosols to the National Oceanic and Atmospheric Administration baseline station at Mauna Loa Observatory, Hawaii, J. Geophys. Res., 104, 1852118533, doi:10.1029/1998JD100083, 1999.

Philipp, A., Bartholy, J., Beck, C., Erpicum, M., Esteban, P., Fettweis, X., Huth, R., James, P., Jourdain, S., Kreienkamp, F., Krennert, T., Lykoudis, S., Michalides, S. C., PiankoKluczynska, K., Post, P., Álvarez, D. R., Schiemann, R., Spekat, A., and Tymvios, F. S.: Cost733cat - a database of weather and circulation type classifications, Phys. Chem. Earth, 35, 360-373, doi:10.1016/j.pce.2009.12.010, 2010.

Pourchet, M., Richon, P., and Sabroux, J. C.: Lead-210 and radon222 anomalies in Mont Blanc snow, French Alps, J. Environ. Radioact., 48, 349-357, doi:10.1016/S0265-931X(99)00084-3, 2000 .
Prévôt, A. S., Dommen, J., and Bäumle, M.: Influence of road traffic on volatile organic compound concentrations in and above a deep Alpine valley, Atmos. Environ., 34, 4719-4726, doi:10.1016/S1352-2310(00)00254-5, 2000.

Purvis, R. M., Lewis, A. C., Carney, R. A., McQuaid, J. B., Arnold, S. R., Methven, J., Barjat, H., Dewey, K., Kent, J., Monks, P. S., Carpenter, L. J., Brough, N., Penkett, S. A., and Reeves, C. E.: Rapid uplift of nonmethane hydrocarbons in a cold front over central Europe, J. Geophys. Res.-Atmos., 108, 4224, doi:10.1029/2002JD002521, 2003.

Reimann, S., Schaub, D., Stemmler, K., Folini, D., Hill, M., Hofer, P., Buchmann, B., Simmonds, P. G., Greally, B. R., and O'Doherty, S.: Halogenated greenhouse gases at the Swiss High Alpine Site of Jungfraujoch (3580 ma.s.1.): continuous measurements and their use for regional European source allocation, J. Geophys. Res.-Atmos., 109, D05307, doi:10.1029/2003JD003923, 2004.

Reimann, S., Vollmer, M., Folini, D., Steinbacher, M., Hill, M., Buchmann, B., Zander, R., and Mahieu, E.: Observations of long-lived anthropogenic halocarbons at the highAlpine site of Jungfraujoch (Switzerland) for assessment of trends and European sources, Sci. Total Environ., 391, 224-231, doi:10.1016/j.scitotenv.2007.10.022, 2008.

Rotach, M. W. and Zardi, D.: On the boundary-layer structure over highly complex terrain: Key findings from MAP, Q. J. Roy. Meteor. Soc., 133, 937-948, doi:10.1002/qj.71, 2007.

Ryan, S.: The wind field around Mauna Loa derived from surface and balloon observations, J. Geophys. Res., 102, 10711-10725, doi:10.1029/97JD00646, 1997.

Schiemann, R. and Frei, C.: How to quantify the resolution of surface climate by circulation types: an example for Alpine precipitation, Phys. Chem. Earth, 35, 403-410, doi:10.1016/j.pce.2009.09.005, 2010.

Seibert, P., Kromp-kolb, H., Kasper, A., Kalina, M., Puxbaum, H., Jost, D. T., Schwikowski, M., and Baltensperger, U.: Transport of polluted boundary layer air from the Po Valley to high-alpine sites, Atmos. Environ., 32, 3953-3965, doi:10.1016/S13522310(97)00174-X, 1998.

Sesana, L., Caprioli, E., and Marcazzan, G. M.: Long period study of outdoor radon concentration in Milan and correlation between its temporal variations and dispersion properties of atmosphere, J. Environ. Radioact., 65, 147-160, doi:10.1016/S0265931X(02)00093-0, 2003.

Stohl, A., Spichtinger-Rakowsky, N., Bonasoni, P., Feldmann, H., Memmesheimer, M., Scheel, H. E., Trickl, T., Hübener, S., Ringer, W., and Mandl, M.: The influence of stratospheric intrusions on alpine ozone concentrations, Atmos. Environ., 34, 1323-1354, doi:10.1016/S1352-2310(99)00320-9, 2000.

Stohl, A., Seibert, P., Arduini, J., Eckhardt, S., Fraser, P., Greally, B. R., Lunder, C., Maione, M., Mühle, J., O’Doherty, S., Prinn, R. G., Reimann, S., Saito, T., Schmidbauer, N., Simmonds, P. G., Vollmer, M. K., Weiss, R. F., and Yokouchi, Y.: An analytical inversion method for determining regional and global emissions of greenhouse gases: Sensitivity studies and application to halocarbons, Atmos. Chem. Phys., 9, 1597-1620, doi:10.5194/acp-91597-2009, 2009.

Szegvary, T., Leuenberger, M. C., and Conen, F.: Predicting terrestrial ${ }^{222}$ Rn flux using gamma dose rate as a proxy, Atmos. Chem. Phys., 7, 2789-2795, doi:10.5194/acp-7-2789-2007, 2007. 
Szegvary, T., Conen, F., and Ciais, P.: European ${ }^{222}$ Rn inventory for applied atmospheric studies, Atmos. Environ., 43, 1536-1539, doi:10.1016/j.atmosenv.2008.11.025, 2009.

Trickl, T., Feldmann, H., Kanter, H.-J., Scheel, H.-E., Sprenger, M., Stohl, A., and Wernli, H.: Forecasted deep stratospheric intrusions over Central Europe: case studies and climatologies, Atmos. Chem. Phys., 10, 499-524, doi:10.5194/acp-10-499-2010, 2010.

Uglietti, C., Leuenberger, M., and Brunner, D.: European source and sink areas of $\mathrm{CO}_{2}$ retrieved from Lagrangian transport model interpretation of combined $\mathrm{O}_{2}$ and $\mathrm{CO}_{2}$ measurements at the high alpine research station Jungfraujoch, Atmos. Chem. Phys., 11, 8017-8036, doi:10.5194/acp-11-8017-2011, 2011.

van der Laan, S., van der Laan-Luijkx, I. T., Zimmermann, L., Conen, F., and Leuenberger, M.: Net $\mathrm{CO}_{2}$ surface emissions at Bern, Switzerland inferred from ambient observations of $\mathrm{CO}_{2}, \delta\left(\mathrm{O}_{2} / \mathrm{N}_{2}\right)$, and ${ }^{222} \mathrm{Rn}$ using a customized radon tracer inversion, J. Geophys. Res. [Atmos.], 119, 2013JD020307, doi:10.1002/2013JD020307, 2014.

Vogel, F. R., Thiruchittampalam, B., Theloke, J., Kretschmer, R., Gerbig, C., Hammer, S., and Levin, I.: Can we evaluate a finegrained emission model using high-resolution atmospheric transport modelling and regional fossil fuel $\mathrm{CO}_{2}$ observations?, Tellus B, 65, 18681, doi:10.3402/tellusb.v65i0.18681, 2013.

Weigel, A. P., Chow, F. K., and Rotach, M. W.: The effect of mountainous topography on moisture exchange between the "surface" and the free atmosphere, Bound.-Lay. Meteorol., 125, 227-244, doi:10.1007/s10546-006-9120-2, 2006.

Weiss-Penzias, P., Jaffe, D. A., Swartzendruber, P., Dennison, J. B., Chand, D., Hafner, W., and Prestbo, E.: Observations of Asian air pollution in the free troposphere at Mount Bachelor Observatory during the spring of 2004, J. Geophys. Res.-Atmos., 111, D10304, doi:10.1029/2005JD006522, 2006.

Weissmann, M., Braun, F. J., Gantner, L., Mayr, G. J., Rahm, S., and Reitebuch, O.: The Alpine mountain-plain circulation: airborne doppler lidar measurements and numerical simulations, Mon. Weather Rev., 133, 3095-3109, doi:10.1175/MWR3012.1, 2005.

Whiteman, C. D.: Mountain meteorology: fundamentals and applications, Oxford University Press, New York, Oxford, 376 pp., 2000 .

Whittlestone, S. and Zahorowski, W.: Baseline radon detectors for shipboard use: development and deployment in the First Aerosol Characterization Experiment (ACE 1), J. Geophys. Res., 103, 16743-16751, doi:10.1029/98JD00687, 1998.

Williams, A. G., Zahorowski, W., Chambers, S., Griffiths, A., Hacker, J. M., Element, A., and Werczynski, S.: The vertical distribution of radon in clear and cloudy daytime terrestrial boundary layers, J. Atmos. Sci., 68, 155-174, doi:10.1175/2010JAS3576.1, 2011.

Williams, A. G., Chambers, S., and Griffiths, A.: Bulk mixing and decoupling of the nocturnal stable boundary layer characterized using a ubiquitous natural tracer, Bound.-Lay. Meteorol., 149, 381-402, doi:10.1007/s10546-013-9849-3, 2013.
WMO: World Data Centre for Greenhouse Gases (WDCGG), available at: http://ds.data.jma.go.jp/gmd/wdcgg/ (last access: 1 October 2012), 2012.

Xia, Y., Sartorius, H., Schlosser, C., Stöhlker, U., Conen, F., and Zahorowski, W.: Comparison of one- and two-filter detectors for atmospheric ${ }^{222} \mathrm{Rn}$ measurements under various meteorological conditions, Atmos. Meas. Tech., 3, 723-731, doi:10.5194/amt-3723-2010, 2010.

Xia, Y., Conen, F., and Alewell, C.: Total bacterial number concentration in free tropospheric air above the Alps, Aerobiologia, 29, 153-159, doi:10.1007/s10453-012-9259-x, 2013.

Yamazawa, H., Miyazaki, T., Moriizumi, J., Iida, T., Takeda, S., Nagara, S., Sato, K., and Tokizawa, T.: Radon exhalation from a ground surface during a cold snow season, Int. Congr. Ser., 1276, 221-222, doi:10.1016/j.ics.2004.11.153, 2005.

Zahorowski, W., Chambers, S., and Henderson-Sellers, A.: Ground based radon-222 observations and their application to atmospheric studies, J. Environ. Radioact., 76, 3-33, doi:10.1016/j.jenvrad.2004.03.033, 2004.

Zahorowski, W., Griffiths, A. D., Chambers, S. D., Williams, A. G., Law, R. M., Crawford, J., and Werczynski, S.: Constraining annual and seasonal radon-222 flux density from the Southern Ocean using radon-222 concentrations in the boundary layer at Cape Grim, Tellus B, 65, 19622, 2013.

Zardi, D. and Whiteman, C. D.: Diurnal mountain wind systems, in: Mountain Weather Research and Forecasting, edited by: Chow, F. K., Wekker, S. F. J. D., and Snyder, B. J., Springer Atmospheric Sciences, 35-119, Springer Netherlands, 2013.

Zellweger, C., Ammann, M., Buchmann, B., Hofer, P., Lugauer, M., Rüttimann, R., Streit, N., Weingartner, E., and Baltensperger, U.: Summertime $\mathrm{NO}_{\mathrm{y}}$ speciation at the Jungfraujoch, $3580 \mathrm{~m}$ above sea level, Switzerland, J. Geophys. Res.-Atmos., 105, 66556667, doi:10.1029/1999JD901126, 2000.

Zellweger, C., Forrer, J., Hofer, P., Nyeki, S., Schwarzenbach, B., Weingartner, E., Ammann, M., and Baltensperger, U.: Partitioning of reactive nitrogen $\left(\mathrm{NO}_{\mathrm{y}}\right)$ and dependence on meteorological conditions in the lower free troposphere, Atmos. Chem. Phys., 3, 779-796, doi:10.5194/acp-3-779-2003, 2003.

Zellweger, C., Hüglin, C., Klausen, J., Steinbacher, M., Vollmer, M., and Buchmann, B.: Inter-comparison of four different carbon monoxide measurement techniques and evaluation of the long-term carbon monoxide time series of Jungfraujoch, Atmos. Chem. Phys., 9, 3491-3503, doi:10.5194/acp-9-3491-2009, 2009.

Zhang, K., Wan, H., Zhang, M., and Wang, B.: Evaluation of the atmospheric transport in a GCM using radon measurements: sensitivity to cumulus convection parameterization, Atmos. Chem. Phys., 8, 2811-2832, doi:10.5194/acp-8-2811-2008, 2008.

Zhang, K., Feichter, J., Kazil, J., Wan, H., Zhuo, W., Griffiths, A. D., Sartorius, H., Zahorowski, W., Ramonet, M., Schmidt, M., Yver, C., Neubert, R. E. M., and Brunke, E.-G.: Radon activity in the lower troposphere and its impact on ionization rate: a global estimate using different radon emissions, Atmos. Chem. Phys., 11, 7817-7838, doi:10.5194/acp-11-7817-2011, 2011. 